\title{
Deposit Insurance, Regulatory Forbearance and Economic Growth: Implications for the Japanese Banking Crisis*
}

\author{
Robert Dekle \\ University of Southern California \\ Kenneth Kletzer \\ University of California, Santa Cruz
}

January 2004

\begin{abstract}
An endogenous growth model with financial intermediation is used to show how public deposit insurance and weak prudential regulation can lead to banking crises and permanent declines in economic growth. The impact of regulatory forbearance on investment, saving and asset price dynamics under perfect foresight are derived in the model. The assumptions of the theoretical model are based on essential features of the Japanese financial system and its regulation. The model demonstrates how banking and growth crises can evolve under perfect foresight. The dynamics for economic aggregates and asset prices predicted by the model are shown to be generally consistent with the experience of the Japanese economy and financial system through the 1990s. We also test our maintained hypothesis of rational expectations using asset price data for Japan over the 1980s and 1990s. An implication of our analysis is that delaying the resolution of banking crises adversely affects future economic growth.
\end{abstract}

*The authors gratefully acknowledge helpful suggestions and comments made by participants in the CESifo Venice Workshop, July 2003, and the NBER/CEPR/CIRJE/EIJS Japan Project Meeting, Tokyo, September 2003. Several points and suggestions made by our discussants at these respective meetings, Takeo Hoshi and David Smith, are incorporated in this version. We thank the organizers of each meeting for including our paper. 


\section{Introduction}

Since the early summer of 2003, Japan started to recover from its long recession. With this recovery, the non-performing loan problems of the major banks appears to be abating. The major banks were helped by large injections of equity from the government and a recovering economy that boosted profits, allowing the major banks to increase their loan-loss reserves and capital-asset ratios. However, difficulties persist with the regional banks, which have been slow to write-off their non-performing loans. Moreover, the growth prospects for the Japanese economy are still uncertain. The persistent difficulties facing the banking sector are a legacy of weak government financial regulation and prudential supervision. This paper considers the possibility that public policy towards the financial system is the root cause of the Japanese banking and growth crisis.

A simple endogenous growth model with a bank-centered financial system is presented and solved for equilibrium in closed-form. Three stylized facts about the Japanese financial are incorporated into the assumptions of our model economy. Domestic investment is financed primarily by bank loans and equity issues. The government provides deposit insurance guarantees to the holders of domestic bank deposits. Prudential regulation and enforcement is weak leading to rises in the non-performing assets held by banks and the deposit insurance liability of the government over time. In our model, banks can accumulate non-performing loans against deposit liabilities when the government guarantees deposits and fails to monitor additions to bank loan-loss reserves.

In the theoretical model, production displays constant returns to a single accumulable factor, capital, and is subject to idiosyncratic productivity shocks. Bank financing of investment by firms dominates direct lending by savers to firms. Bank loans are derived as constrained optimal contracts under standard information assumptions. Productivity shocks are independent across a continuum of firms, and there is no aggregate uncertainty. In equilibrium, the asset portfolios of both banks and households (which hold both deposits and corporate equities) are perfectly diversified. The analysis focuses on how public sector deposit guarantees and regulatory forbearance lead to the accumulation of non-performing bank assets, deposit insurance liabilities and falling growth rates in the endogenous growth model. It shows how a banking crisis can evolve endogenously as investment and output growth decline in the absence of systemic shocks.

Weak prudential regulation is interpreted in our model as a failure of the government to enforce loan-loss reserve accumulations by banks against non-performing corporate loans or, equivalently, the writing off of non-performing assets. In this case, banks are able to make dividend payments to their shareholders against the interest contracted on both performing and non-performing assets. Deposit insurance allows the banks to transfer resources from the government to their shareholders. With regulatory forbearance, the 
output growth rate falls gradually in equilibrium as non-performing bank loans grow in the economy. The longer the government fails to intervene, the lower the growth rate falls towards zero. If the government fails to intervene before a critical date, the banks will be unable to meet the deposit withdrawal demands of households for consumption leading to a banking crisis. A banking crisis arises endogenously under perfect foresight in our model.

The dynamics for output, consumption and investment under regulatory forbearance and deposit insurance predicted by the model are compared to the recent experience of the Japanese economy. A feature of our model is that we can solve for the equity values of the banking sector and the non-bank corporation sector. A prediction special to our model is that the relative value of bank stocks to the aggregate stock market falls ahead of a banking crisis, while the value of corporate equity can be rising. The model also predicts a collapse in the market for collateral at the moment of the crisis. We also compare these implications to the data for Japan. Our empirical work begins with a test of the maintained hypothesis of perfect foresight. We compare the experience of Japan to the model and test the relationships in our model using structural vector autoregressions.

We argue that the data are consistent with our simple dynamic model that assumes that asset prices correctly reflect fundamentals. We show that for Japan's recent economic history, fundamentals are important in explaining Japanese stock returns and that the role of bubbles in affecting stock returns may be small or superfluous. Surprisingly, we show that these results hold even for the 1980s, when Japanese equity prices skyrocketed. The data on Japanese macroeconomic aggregates, consumption, investment and growth, are also roughly consistent with the comparative dynamics of our model.

Given that Japanese stock prices roughly correspond to fundamentals, we test the theoretical prediction in our model that the ratio of the value of bank equities to the overall stock market declines before the crisis, and ahead of other macroeconomic aggregates. Our causality tests are consistent with our theory: the ratio of the value of bank equities to the overall stock market precedes the movement in other macroeconomic aggregates, for example, the investment-output ratio.

The model of banking crises presented here complements the traditional view of Japan's banking crisis in the 1990s. The traditional view places blame for Japan's banking crisis on the manner of financial sector deregulation initiated in the middle of the 1970s. ${ }^{1}$ In that view, as alternative financial instruments were introduced, large, internationally-oriented firms began to raise funds directly in the domestic and foreign bond markets. As the large banks started to lose their highest quality corporate borrowers in the late 1980s, they began lending to smaller firms. When the asset-market boom for Japan in the late 1980s collapsed, the Japanese economy began its prolonged stagnation, and the non-performing assets of the banking system 
rose rapidly. Despite the rise in direct borrowing by major corporations, Japanese financial intermediation is dominated by commercial banks. Cargill, Hutchison and Ito [1997] and Cargill [1999] emphasize, as we do, the importance of explicit and implicit deposit guarantees and of regulatory forbearance in the creation of the crisis. This paper contributes a formal model of credit market dynamics that complements our earlier paper, Dekle and Kletzer [2003]. ${ }^{2}$

Our model is one of the few general equilibrium models that analyze the Japanese financial and growth crisis of the 1990s. Banking crises affect capital accumulation and economic growth, while low growth rates exacerbate banking crises. Because of the endogenous mutual relationship between banking crises and growth, partial equilibrium models are severely limited. Three other papers analyze the Japanese economy in the 1990s using a general equilibrium framework. Hayashi and Prescott [2002] present and calibrate a real business cycle model for Japan to show how the decrease in labor supply and total factor productivity growth can account for the growth slump of the 1990s. Hayashi and Prescott argue that credit constraints were not important for reducing investment rates, but they also suggest that weakness of the banking sector might have played a role in lowering the productivity of investment. As in our model, Barseghyan [2002] emphasizes delays in government bailouts of the banking system in an overlapping generations model. In his model, when the government delays bailouts, banks use new deposits to meet the withdrawals by old depositors, as in a Ponzi scheme. Barseghyan calibrates his model to Japanese data and finds a favorable comparison to Japanese growth in the 1990s. The third paper is our earlier model (Dekle and Kletzer [2003]) of endogenous banking crises which presents a somewhat different model and empirical analysis for Japan.

The next section discusses the stylized facts about the Japanese financial system that motivate the simple assumptions of our analysis. Sections 3, 4 and 5 present the endogenous growth model, analyze the effects of weak prudential supervision in the presence of deposit insurance and depict how a banking crisis can occur under perfect foresight, in turn. The next two sections show how our model is consistent with the data and present some econometric analysis supporting the main implications of our model. Section 8 concludes.

\section{Three Characteristics of the Financial System of Japan}

The theoretical model of this paper incorporates three characteristics of the Japanese financial system into its assumptions. These assumptions are central to the dynamics of economic growth and domestic financial markets before and after a banking crisis that are derived in the model. The first is the predominance of commercial bank intermediation of corporate finance, modeled as arising from the 
informational advantage of banks over other lenders. The second is the prospect of government-provided deposit insurance, or public sector bailouts of the domestic banking sector. The third is supervisory forbearance and the absence of effective prudential regulation of the banking sector. In this section, we review these three aspects of the financial system of Japan to support the use of our assumptions.

Bank loans comprise an exceptionally large share of Japanese corporate and other firm debt by international comparison. Typically, only large, well-capitalized firms have been able to funds on bond markets. Small- and medium-sized domestic firms continued to rely on bank financing through the 1990s (see Hoshi and Kayshap [2001]). The fraction of small- and medium-sized business loans to total loans increased from 73 percent over the period, 1977-86, to 78 percent over the period, 1987-1990, as reported by Ogawa and Kitasaka [2000]. This reliance on bank financing was especially prevalent for small- and medium-sized firms in the service, construction and real estate sectors. Between 1987-1990, while bank loans to the manufacturing sector increased by 1 percent, loans to the service, construction, and real estate sectors rose by 14 percent, 7 percent, and 18 percent, respectively (Ogawa and Kitasaka [2000]).

Japanese bank deposits have been implicitly guaranteed by the government, traditionally through the "convoy system," or "purchase and assumption," rescue, in which a healthy bank is encouraged by the government to provide assistance to a troubled one. Recently, however, the government has provided implicit guarantees through direct injections of capital to troubled banks.

The government's system of explicit and implicit guarantees implies that no deposits, large or small, were ever at risk in postwar Japan. Before 1991, the official policy was there would be "no failures of financial institutions." Since 1991, banks have failed; for example, from 1991 to 1995, eleven small banks were formally declared insolvent. However, the guarantees meant that no depositor ever lost any funds.

In our model, the failure of authorities to monitor the accumulation of non-performing assets and holding of loan-loss reserves by banks until the deposit insurance liability of the government has reached either a critical level leads to financial crises and falling GDP growth.

Awareness of the problems with the existing bank supervisory regime led the government to move financial supervision and examination from the Ministry of Finance to the new independent Financial Supervisory Agency in 1996. The government also tried to replace discretion of supervisors by a rule-based scheme, the Prompt Corrective Action system, in 1998. Under Prompt Corrective Action, regulators are required to intervene quickly at poorly capitalized banks. For example, regulators are required to close a bank if the bank's capital-asset ratio falls below zero.

Initially, these institutional changes led to improvements in prudential supervision and enforcement. The Financial Supervisory Agency moved to examine the books of all banks which led to the immediate 
closure of five smaller banks. However, as the immediate financial crisis subsided, the regulations were redefined to make them less restrictive. The introduction of the Prompt Corrective Action policy was delayed a year. Accounting standards were changed, so that banks could make their financial statements appear better than they were. Some banks that should have been closed under the statutes were allowed to continue operating because the closure of these banks would add to local unemployment.

\section{A Model of Growth and Banking Crises}

This section presents a general equilibrium model of endogenous growth with bank-intermediated investment to show how publicly-funded deposit insurance and prudential supervisory or regulatory failures combine to affect investment and output growth. The model differs from our earlier model, Dekle and Kletzer [2003] in a number of respects. There are two important innovations in this paper. The first is that we use an open economy with a banking sector that faces competition for deposits at a given real rate of interest. The second is the production structure. Together these lead to a significant qualitative difference in the dynamics leading up to a bank liquidity crisis.

\subsection{Production and Bank Lending}

Output is produced from capital alone using a constant returns to scale technology with stochastic productivity. There is a continuum of firms, indexed across the unit interval, and productivity shocks are independent and identically distributed across firms and over time for each firm. The net output for a typical firm is given by

$$
y_{t}^{j}=\alpha_{t}^{j} k_{t}^{j}
$$

where $y_{t}^{j}, k_{t}^{j}$ and $\alpha_{t}^{j}$ denote output, the capital stock and the realized net productivity for firm $j$ at time $t$, respectively. There is no depreciation for simplicity, and investment is assumed to be irreversible (this assumption is used later). For simplicity, productivity realizations, $\alpha_{t}$, are distributed uniformly over the common interval, $0 \leq \alpha_{t} \leq \alpha$. With a continuum of firms, aggregate output is not stochastic and is given by

$$
y_{t}=\frac{\alpha}{2} k_{t}
$$

where $y_{t}$ and $k_{t}$ denote aggregate net output and the capital stock at time $t$, respectively.

Savings is undertaken by a continuum of households who acquire bank deposits and hold equities in firms and banks. All households are identical and infinitely-lived, so that there is no trade in firm or bank equity in equilibrium. Capital accumulation is debt-financed, and any firm income net of interest 
is immediately paid in dividends to firm shareholders. A standard informational asymmetry motivates the predominance of bank lending over direct lending by households and generates conventional loan contracts. Firms observe their productivities in each period at no cost, but lenders can only observe it at a positive cost. Banks are able to make these observations at a lower cost than households so all lending is intermediated by banks in equilibrium. Townsend [1979] and Diamond [1984] show that the standard loan contract is optimal in this context (in a static setting). ${ }^{3}$ For algebraic simplicity, the costs of observing a corporate borrower's output is proportional to firm's capital (for example, auditing costs rise with firm size).

The expected net return for a one-period bank loan to a firm is given by

$$
\frac{1}{\alpha} \int_{r^{\ell}}^{\alpha} \ell_{t}^{j}\left(1+r_{t}^{\ell}\right) d \alpha_{t}+\frac{1}{\alpha} \int_{0}^{r^{\ell}}\left(1+\alpha_{t}-\gamma\right) k_{t}^{j} d \alpha_{t}-(1+r) \ell_{t}^{j},
$$

where $r_{t}^{\ell}$ is the loan rate of interest, $r$ is the deposit rate of interest, $\gamma$ represents auditing costs and $\ell_{t}$ is the size of the loan. Under our assumptions, if a firm has no accumulated unpaid past net interest, the firm's debt, $\ell_{t}$, just equals its capital stock, $k_{t}$. The equilibrium rate of interest, $r^{\prime}$, charged to a single-period loan in a competitive market in this case is given by

$$
r^{\prime}\left(1-\frac{1}{2} \frac{r^{\prime}}{\alpha}-\frac{\gamma}{\alpha}\right)=r
$$

With positive probability, $\frac{r^{\prime}}{\alpha}$, the earnings of the firm will fall short of the net interest on the loan in period $t$. The loss to the bank is accounted for by the interest rate spread, $r^{\prime}-r$, in equation (2).

The interest rate that maximizes a lender's expected return in this economy is $\alpha-\gamma$ (per unit of firm capital). The interest charged can reach this level if banks rollover unpaid interest obligations into longer term loans increasing interest charges as a share of firm revenues. Under perfect competition, the initial interest rate charged to firms would be less than $r^{\prime}$. However, rolling over unpaid interest in this economy increases the future probability that firm revenues will be less than interest costs. This means that the probability that banks bear and pass on intermediation costs, $\gamma k$, rises with rollovers. Therefore, in present value, intermediation costs are minimized under single-period contracts. ${ }^{4}$ Since these are deadweight costs (passed on to firms in interest with competitive banking), short-term contracts charging an interest rate equal to $r^{\prime}$ are efficient in this economy. Additional institutional assumptions could be made to get long-term contracts, but the only effect on the balanced growth path of this economy would be quantitative, the interest rate would be $\alpha-\gamma$ rather than $r^{\prime}$. We use the constrained optimal contract for this standard model.

The aggregate dynamics of the economy are easy to analyze because there is no aggregate uncertainty 
with a continuum of firms. The portfolio of each of a finite number of banks is fully diversified with the continuum of firms drawing productivity realizations from independent and identical distributions. In the balanced growth path, the flow of aggregate net output equals $\left(\frac{\alpha}{2}-\frac{\gamma r^{\prime}}{\alpha}\right) k_{t}$, and the capital stock evolves according to the resource constraint,

$$
\dot{k}=\left(\frac{\alpha}{2}-\frac{\gamma r^{\prime}}{\alpha}\right) k_{t}-c_{t},
$$

where $c_{t}$ is aggregate consumption. Aggregate flow profits of the corporate sector are given by

$$
d_{t}=\frac{1}{\alpha} \int_{\widehat{r}}^{\alpha}\left(\widetilde{\alpha}-r^{\prime}\right) k_{t} d \widetilde{\alpha}=\frac{\left(\alpha-r^{\prime}\right)^{2}}{2 \alpha} k_{t},
$$

which is paid in dividends to households for holding shares of corporate equities.

\subsection{Household Consumption and Saving}

The representative household seeks to maximize its utility,

$$
U_{t}=\int_{t}^{\infty} \frac{c_{s}^{1-\sigma}}{1-\sigma} e^{-\rho(s-t)} d s
$$

with respect to its consumption plan given its flow budget identity,

$$
\dot{a}=r a_{t}+d_{t}+x_{t}-c_{t}
$$

the conventional solvency constraint,

$$
\lim _{s \rightarrow \infty} e^{-r(s-t)} a_{s} \geq 0
$$

and initial deposit holdings, $a_{t} . x_{t}$ represents bank dividends. The number of firms and banks is fixed so that equity shares cannot be accumulated in the aggregate, hence by the representative household in equilibrium.

Households completely avoid any corporate dividend income risk by holding a fully diversified portfolio of corporate stocks with a continuum of firms realizing independent productivity shocks. In equilibrium at each date, a proportion $\left(1-r^{\prime} / \alpha\right)$ of each bank's loans pay interest $r^{\prime}$ per unit of capital, and a proportion $r^{\prime} / \alpha$ pay average interest $\frac{1}{2 \alpha} r^{2}$. In addition, the flow cost of bank intermediation is equal to the current auditing costs, $\left(r^{\prime} / \alpha\right) \gamma k_{t}$.

The assumptions that allow complete diversification of productivity risk by households as shareholders and depositors allow us to show how inadequate bank monitoring and prudential regulation with deposit insurance affect investment, output growth and asset prices. Incomplete risk diversification opportunities or incentives, as emphasized in the agency models proposed by Dekle and Kletzer [2002a and b] could raise the social costs created by inadequate supervision and regulation of intermediaries or firms. ${ }^{5}$ 


\subsection{Benchmark Equilibrium}

We take the case in which the government requires banks to hold reserves against any loan losses they accumulate and enforces this regulation continuously as a benchmark. In equilibrium, the losses of banks on a proportion $r^{\prime} / \alpha$ of the total loan portfolio, equal to

$$
\left(\frac{1}{2 \alpha} r^{\prime 2}+\frac{r^{\prime}}{\alpha} \gamma-r \frac{r^{\prime}}{\alpha}\right) k_{t}
$$

are offset by surpluses on a proportion $\left(\alpha-r^{\prime}\right) / \alpha$ given by

$$
\frac{\alpha-r^{\prime}}{\alpha}\left(r^{\prime}-r\right) k_{t}
$$

With continuous loan-loss reserving enforced, the banks' profits on some loans just match write-offs on other loans. The profits of each bank are always zero, and the value of bank equity is always zero. The government accumulates no liabilities associated with deposit insurance or other guarantees to the banking system, implicit or explicit.

The equilibrium path for the economy is found by maximizing representative household utility with respect to the consumption plan given the aggregate resource constraint,

$$
\dot{k}=\left(\frac{\alpha}{2}-\frac{\gamma r^{\prime}}{\alpha}\right) k_{t}-c_{t},
$$

and the predetermined capital stock under perfect foresight. The parameter restriction,

$$
\left(\frac{\alpha}{2}-\frac{\gamma \widehat{r}}{\alpha}\right)-\left(\frac{r-\rho}{\sigma}\right)>0
$$

assures the existence of a solution. Under perfect foresight, equilibrium consumption is given by

$$
c_{t}=\left(\frac{\alpha}{2}-\frac{\gamma r^{\prime}}{\alpha}-\frac{r-\rho}{\sigma}\right) k_{t}
$$

and the equilibrium growth rate of consumption, capital and output is

$$
\frac{\dot{c}}{c}=\frac{\dot{k}}{k}=\frac{\dot{y}}{y}=\frac{r-\rho}{\sigma} .
$$

The growth rate remains constant over the entire infinite horizon. In this case, net household savings just equals economy-wide capital accumulation,

$$
s_{t}=\frac{r-\rho}{\sigma} k_{t}=\dot{k}_{t} .
$$

Imposing the assumption that $r>\rho$ allows positive investment and output growth. Note that the gross earnings on household bank deposits equal $r k_{t}$, and net withdrawals from bank deposits equal $\left(r-\frac{r-\rho}{\sigma}\right) k_{t}$. Bank deposits, $a$, grow at the same rate as output, $\frac{r-\rho}{\sigma}$. 
The aggregate value of corporate equity is given by the present value of dividends, discounted at the household's opportunity rate of interest,

$$
V_{t}^{f}=\int_{t}^{\infty} d_{s} e^{-r(s-t)} d s=\int_{t}^{\infty} \frac{\left(\alpha-r^{\prime}\right)^{2}}{2 \alpha} k_{s} e^{-r(s-t)} d s=\frac{\left(\alpha-r^{\prime}\right)^{2}}{2 \alpha} k_{t}\left(r-\frac{r-\rho}{\sigma}\right)^{-1},
$$

which rises proportionally with the capital stock and output.

\section{Growth with Deposit Guarantees and Regulatory Forbearance}

To analyze the effects of weak prudential supervision in the presence of publicly funded deposit insurance, we assume that government regulators do not enforce loan loss reserve requirements. They do not audit the balance sheets of the banks and require reserving against accumulated losses on individual loans. This allows banks to keep uncollected interest on their balance sheets as performing assets without using the profits earned on other loans to cover the losses. By doing so, the banks can pay dividends from current loan profits without subtracting current loan losses.

If the liability of shareholders to the holders of bank deposits is limited, banks have an incentive to accumulate non-performing assets and pay out dividends from current loan income. When a bank becomes insolvent, shareholders are spared from liability so that the value of shareholder equity is bounded from below by zero. As a bank accumulates losses as non-performing loans without also saving the surplus, $r^{\prime}-r$, from repaid loans, these losses will be borne eventually by shareholders, depositors or the government through a depositor bailout. If depositors bear the cost and cannot monitor the bank's accounts $^{6}$, then the rate of interest received by depositors will be driven down and the growth rate of the economy declines.

In our case, the government provides deposit insurance but does not audit the bank loan portfolios or monitor loan-loss reserves. By accumulating non-performing assets and paying dividends equal to the loan income from performing assets, a bank accumulates a deposit insurance claim against the government. The liabilities of the banking system equal the total deposits of savers, and its assets equal the sum of the corporate sector capital stock and the total deposit insurance claim against the government. That is, the accumulated loan losses are assets, but they are claims against the government's deposit insurance plan rather than against the corporate sector. The deposit insurance liability of the government is a public debt held by the banks. The assets of the banking sector, which are equal to its deposit liabilities, are the sum of $k_{t}$ and government debt, $b_{t}$. Total household interest-bearing assets equal bank deposits, so that $a_{t}=k_{t}+b_{t}$ in equilibrium. The deposit insurance claim of the banks against deposits contrasts with bonds or other forms of public debt issued by the treasury. The deposit insurance liability of the government is 
created endogenously by the banking sector.

So that banks pay positive dividends in equilibrium, some form of imperfect competition in banking needs to be introduced. This model does not require us to be very articulate about imperfect competition. For simplicity, we let banks compete in individual initial loans but pay out dividends against individual loan profits and accumulate deposit insurance claims against accumulated individual loan losses with a fixed number of banks. The loan rate of interest is $r^{\prime}$ as defined by equation (2). If banks did compete away any profits by offering lower interest rates to the corporate sector, the deposit insurance liability of the government will finance dividends to corporate shareholders in exactly the same amount as will go to the bank shareholders here. Since all shares are held by the representative household, nothing but the division between bank dividends and corporate dividends is affected by our assumption.

We consider two simple institutional constraints on the flow of dividends that a bank can pay at each date. One is that if the bank cannot meet its net withdrawal demand at any time, it is illiquid and the government immediately intervenes. The second constraint is that banks cannot accumulate non-performing assets faster than the flow of unpaid interest obligations which equal

$$
\left(\frac{1}{2 \alpha} r^{2}-r \frac{r^{\prime}}{\alpha}\right) k_{t}
$$

in the aggregate. This is the same as loan profits minus the costs of intermediation given by

$$
\left(r^{\prime}-r-\frac{\gamma r^{\prime}}{\alpha}\right) k_{t}
$$

Total dividends paid to bank equities will equal this amount in equilibrium until regulatory authorities stop allowing the public sector deposit insurance liability to grow. Deposit insurance is a subsidy to shareholders, and banks maximize the value of shareholder equity under limited shareholder liability by making these lump-sum transfers as fast as possible. In this economy, bank dividends are a transfer from the public sector to bank shareholders. The additional institutional assumption is that banks cannot claim larger deposit insurance losses than the deposit cost of accumulated unpaid interest on corporate loans.

We first allow banks to accumulate losses for a fixed period of time, from $t=0$ to $T$. At time $T$, the government intervenes and stops further accumulation of non-performing loans by the banks. Public sector liabilities, $b_{T}$ are determined in equilibrium given $T$, or conversely. The analysis is the same if the government halts the accumulation of deposit insurance liabilities at some time, $T$, or at some maximum liability, $b_{T}$.

Bank dividends,

$$
x_{t}=\left(r^{\prime}-r-\frac{\gamma r^{\prime}}{\alpha}\right) k_{t},
$$


grow with the capital stock until date $T$. The capital stock grows as the difference between bank deposits and the deposit insurance claim of the banks. The deposit insurance liability of the public sector grows as

$$
\dot{b}=r b_{t}+x_{t},
$$

for $0 \leq t \leq T$. The value of bank equity evolves according to

$$
\dot{V}^{b}=r V_{t}^{b}-x_{t}
$$

At time $T$, dividends drop permanently to zero, so that $V^{b}$ must converge to zero at time $T$. Initially, deposit insurance liabilities (equivalently, non-performing loans) are zero, so that $b_{0}=0$. The sum of the public sector liability and banking sector equity, $b+V^{b}$, grows as

$$
\dot{V}^{b}+\dot{b}=r\left(V_{t}^{b}+b_{t}\right)
$$

for $0 \leq t \leq T$. For this period, the government does not recognize or cover its deposit guarantee liabilities.

The solvency constraint for the public sector implies that after time $T$, the government must collect revenue to meet its obligation, $b_{T}$. In this economy, the government does not have access to lump-sum taxes and imposes a tax on interest income (the interest received on deposits) at a constant proportionate rate, $\tau$. The deposit rate of interest from time $T$ on is $\widehat{r}=(1-\tau) r$. The flow-budget identity for the public sector from $T$ onward is

$$
\dot{b}=r b_{t}-\tau r\left(k_{t}+b_{t}\right)=\widehat{r} b_{t}-\tau r k_{t},
$$

and the intertemporal budget constraint for the government is

$$
\int_{0}^{T} x_{t} e^{-r t} d t+e^{-r T} \int_{T}^{\infty} \tau r k_{t} e^{-\widehat{r}(t-T)} d t=e^{-r T} b_{T}+e^{-r T} \int_{T}^{\infty} \tau r k_{t} e^{-\widehat{r}(t-T)} d t=0 .
$$

To simplify the mathematics only, $\tau$ is taken to be constant. For the same reason, $\tau$ is chosen so that the government is solvent and the ratio of government liabilities to deposits stays constant. This keeps the post-tax rate of interest, $\widehat{r}$, and the ratio $b / k$ constant for $t \geq T$.

The equilibrium growth path is derived assuming perfect foresight. That is, households correctly anticipate the future tax on interest earnings imposed at time $T$. The flow-budget identity for the representative household is given by

$$
\dot{k}+\dot{b}=r\left(k_{t}+b_{t}\right)+x_{t}+d_{t}-c_{t}, \quad \text { for } 0 \leq t \leq T,
$$

and

$$
\dot{k}+\dot{b}=\widehat{r}\left(k_{t}+b_{t}\right)+d_{t}-c_{t}, \quad \text { for } t \geq T
$$


Maximizing household utility leads to the equilibrium growth rates of consumption,

$$
\frac{\dot{c}}{c}=\frac{r-\rho}{\sigma}, \quad \text { for } 0 \leq t \leq T,
$$

and

$$
\frac{\dot{c}}{c}=\frac{\widehat{r}-\rho}{\sigma}, \quad \text { for } t \geq T .
$$

Equilibrium consumption is found by integrating the aggregate resource constraint (3) and is given by

$$
c_{t}=\left[\left(1-e^{-\theta(T-t)}\right) \theta^{-1}+e^{-\theta(T-t)}\left(\theta+\frac{r-\widehat{r}}{\sigma}\right)^{-1}\right]^{-1} k_{t}, \quad \text { for } 0 \leq t \leq T,
$$

where

$$
\theta=\frac{\alpha}{2}-\frac{\gamma r^{\prime}}{\alpha}-\frac{r-\rho}{\sigma}
$$

and

$$
c_{t}=\left(\theta+\frac{r-\widehat{r}}{\sigma}\right) k_{t}, \quad \text { for } t \geq T .
$$

Consumption as a share of the capital stock rises monotonically, while the national savings rate falls, over time up to date $T$.

The capital stock grows as

$$
\begin{aligned}
\frac{\dot{k}}{k} & =\left(\frac{\alpha}{2}-\frac{\gamma r^{\prime}}{\alpha}\right)-\frac{c_{t}}{k_{t}} \\
& =\left(\frac{\alpha}{2}-\frac{\gamma r^{\prime}}{\alpha}\right)-\left[\left(1-e^{-\theta(T-t)}\right) \theta^{-1}+e^{-\theta(T-t)}\left(\theta+\frac{r-\widehat{r}}{\sigma}\right)^{-1}\right]^{-1} \\
& \equiv \varphi(T-t, \tau)
\end{aligned}
$$

for $0 \leq t \leq T$, and

$$
\frac{\dot{k}}{k}=\frac{\widehat{r}-\rho}{\sigma}, \quad \text { for } t \geq T .
$$

The function, $\varphi(T-t, \tau)$, is decreasing in $t$ for $t \leq T$, equals $\frac{\hat{r}-\rho}{\sigma}$ for $t=T$ and converges to $\frac{r-\rho}{\sigma}$ as $T-t$ goes to infinity. Under perfect foresight, the investment rate and growth rate of output fall as non-performing bank assets rise. The constraint that banks must remain liquid before date $T$ is not binding if $\widehat{r}-\rho>0 .{ }^{7}$ In the next subsection, we consider the possibility that this inequality does not hold.

To calculate the value of bank equity, recall that shareholder value is maximized if banks pay out the largest possible dividends up to time $T,\left(r^{\prime}-r-\frac{\gamma r^{\prime}}{\alpha}\right) k_{t}$. The stockmarket value of the banking sector 
under perfect foresight is given by

$$
V_{t}^{b}=\int_{t}^{T}\left(r^{\prime}-r-\frac{\gamma r^{\prime}}{\alpha}\right) k_{s} e^{-r(s-t)} d s=\left(r^{\prime}-r-\frac{\gamma r^{\prime}}{\alpha}\right) k_{t} \int_{t}^{T} e^{\int_{t}^{s}(\varphi(T-v, \tau)-r) d v} d s .
$$

Differentiation of equation (23) shows that the ratio of bank equity to the current capital stock, $\frac{V_{t}^{b}}{k_{t}}$, or to gross domestic output, $\frac{V_{t}^{b}}{\left(\alpha / 2-\left(r^{\prime} / \alpha\right) \gamma\right) k_{t}}$, falls monotonically to zero up to time $T$. The total value of bank equity is given by

$$
V_{t}^{b}=\left(r^{\prime}-r-\frac{\gamma r^{\prime}}{\alpha}\right) k_{0} \int_{t}^{T} e^{\int_{0}^{s} \varphi(T-v, \tau) d v} e^{-r(s-t)} d s .
$$

Aggregate corporate equity is given by the present value of dividends as

$$
\begin{aligned}
V_{t}^{f} & =\int_{t}^{T} d_{s} e^{-r(s-t)} d s+e^{-r(T-t)} \int_{T}^{\infty} d_{s} e^{-\widehat{r}(s-T)} d s \\
& =\int_{t}^{T} \frac{\left(\alpha-r^{\prime}\right)^{2}}{2 \alpha} k_{s} e^{-r(s-t)} d s+e^{-r(T-t)} \int_{T}^{\infty} \frac{\left(\alpha-r^{\prime}\right)^{2}}{2 \alpha} k_{s} e^{-\widehat{r}(s-T)} d s \\
& =\frac{\left(\alpha-r^{\prime}\right)^{2}}{2 \alpha} k_{t}\left[\int_{t}^{T} e^{-\int_{t}^{s}(r-\varphi(T-v, \tau)) d v} d s+\left(\widehat{r}-\frac{\widehat{r}-\rho}{\sigma}\right)^{-1} e^{-\int_{t}^{T}(r-\varphi(T-v, \tau)) d v}\right] .
\end{aligned}
$$

After date $T$, the value of corporate equity grows at the same rate as the capital stock and output, $\frac{\hat{r}-\rho}{\sigma}$. Up to time $T$, it also grows proportionately with $k_{t}$ and output if $\sigma=1$, but grows faster than $k_{t}$ if $\sigma>1$ and more slowly than $k_{t}$ if $\sigma<1$. Thus, for an intertemporal elasticity of substitution of one-half

$(\sigma=2)$, typically assumed in calibrated growth models, the value of corporate equity rises faster than gross domestic output up to time $T{ }^{8}$ Although the value of corporate equity is continuous at $T$ under perfect foresight, the growth rate of corporate equity suddenly falls at time $T$ to $\frac{\hat{r}-\rho}{\sigma}$ for $\sigma>1$. This is verified by differentiating equation (25).

The model predicts that the value of bank equity will fall in proportion to gross domestic output before the government realizes its deposit insurance losses in the banking sector. The value of corporate equity rises faster than output before time $T$, and grows with gross domestic output thereafter. A decline in the value of bank equities foreshadows the banking crisis, but a decline in corporate equity does not under perfect foresight.

\section{A Banking Crisis under Perfect Foresight}

In the model economy, banks accumulate claims against the government in the form of unrealized deposit insurance liabilities as they accumulate non-performing loans without offsetting loan-loss reserves on their balance sheets. These public sector liabilities held by the banks balance the difference between their total liabilities to depositors and the real assets (capital) of corporate debtors. In paying dividends 
from what would otherwise be additions to loan-loss reserves, banks create transfer payments from the government to the shareholders. Eventually, the government must raise tax revenue to pay for these transfers and does so by taxing depositors. The transfers are possible because the public sector guarantees deposits, either explicitly or implicitly, without adequately monitoring and controlling the growth of its deposit guarantee indemnity or the accumulation of non-performing loans by banks with positive equity values. $^{9}$

An interpretation of the government's policy is that the government forebears regulation and enforcement until its insurance liability reaches some threshold $\left(b_{T}\right)$. To an extent this characterizes the policies followed by many governments that have subsequently faced banking crises. It is clearly not an optimal policy if monitoring is costless. In the model economy, banks can meet household deposit withdrawal demand, given by equation (19), as long as $\widehat{r} \geq \rho$. The longer it takes the government to stop the growth of its deposit insurance liabilities, the larger is its debt when it finally does intervene and begins to finance its insurance losses by taxing interest. The longer regulatory authorities forebear (that is, the larger is $T$ ), the lower will the rate of investment and the growth rate of output be after time $T$.

To show this, we begin with the government's intertemporal solvency constraint (from equation (14)) written as

$$
\begin{aligned}
0 & =e^{-r T} b_{T}+e^{-r T} \int_{T}^{\infty} \tau r k_{t} e^{-\widehat{r}(t-T)} d t \\
& =e^{-r T} b_{T}+e^{-r T} k_{\mathbf{0}} e^{\int_{0}^{T} \varphi(T-v, \tau) d v} \tau r\left(\widehat{r}-\frac{\widehat{r}-\rho}{\sigma}\right)^{-1}
\end{aligned}
$$

This can be rewritten using the solution for $e^{-r T} b_{T}$ from integrating the growth equation for the government's deposit insurance liability, equation (10). This is

$$
e^{-r T} b_{T}=\int_{0}^{T}\left(r^{\prime}-r-\frac{\gamma r^{\prime}}{\alpha}\right) k_{s} e^{-r(s-t)} d s=\left(r^{\prime}-r-\frac{\gamma r^{\prime}}{\alpha}\right) k_{0} \int_{0}^{T} e^{\int_{t}^{s}(\varphi(T-v, \tau)-r) d v} d s .
$$

The solvency constraint becomes

$$
\left(r^{\prime}-r-\frac{\gamma r^{\prime}}{\alpha}\right) \int_{0}^{T} e^{\int_{t}^{s}(\varphi(T-v, \tau)-r) d v} d s+e^{\int_{0}^{T}(\varphi(T-v, \tau)-r) d v} \tau r\left(\widehat{r}-\frac{\widehat{r}-\rho}{\sigma}\right)^{-1}=0,
$$

where $\widehat{r}=(1-\tau) r$. Total differentiation with respect to $T$ and $\tau$ shows that $\tau$, and public debt, $b_{T}$, are increasing in $T$. The long-run growth rate,

$$
\frac{\dot{y}}{y}=\frac{\dot{k}}{k}=\frac{\widehat{r}-\rho}{\sigma},
$$

falls as the tax rate rises. 
For a long enough period of regulatory forbearance, public debt will rise sufficiently so that the tax rate must be raised to the point that the post-tax interest rate on deposits falls below the subjective rate of discount and the long-run equilibrium growth rate is negative. In this case, household savings will be negative, and households will withdraw deposits on net from the banking system. These net withdrawals will force the banks to reduce lending to corporations forcing corporations to scrap capital. Our assumption that investment is irreversible (as an extreme case of downward investment adjustment costs) imposes an upper bound on $\tau$, and therefore on $T$.

The growth rate of the economy given by equation (21) falls continuously until time $T$ to its long-run level given by $\frac{r(1-\tau)-\rho}{\sigma}$. If $r(1-\tau)<\rho$, then the growth rate falls to zero at some time $\bar{T}$ before date $T$. At date $\bar{T}$, the banking system will able to just meet the withdrawal demands of depositors using the interest paid by corporations less costs of intermediation,

$$
\left(r^{\prime}-\frac{\gamma r^{\prime}}{\alpha}\right) k_{t}
$$

The growth of deposits, the capital stock and gross domestic output all reach zero at time $\bar{T}$. If the deposit insurance liability of the government continues to rise after the growth rate reaches zero at time $\bar{T}$, the anticipated tax rate on interest must also rise. In this economy (in contrast that in Dekle and Kletzer [2003]), the pre-tax deposit rate of interest can rise. Bank returns on loans are maximized when the loan rate of interest reaches $\alpha-\gamma$, implying a maximum pre-tax deposit rate of interest given by

$$
r^{*}=\frac{(\alpha-\gamma)^{2}}{2 \alpha}
$$

Corporate profits fall to

$$
d^{*}=\frac{\alpha^{2}-(\alpha-\gamma)^{2}}{2 \alpha} k
$$

while unpaid interest rises from

$$
\frac{r^{\prime 2}}{2 \alpha} k \quad \text { to } \quad \frac{(\alpha-\gamma)^{2}}{2 \alpha} k
$$

where $k$ is constant since the growth rate is zero. The social costs of intermediation also rise to $\gamma(\alpha-\gamma) / \alpha$ so that total dividends that are paid out under regulatory forbearance decline. As the pre-tax rate of interest, however, the post-tax rate of interest must remain equal to the discount rate, $\rho$. At time $\widehat{T}$, the interest rate reaches $r^{*}$ with a tax rate given by $r^{*}\left(1-\tau^{*}\right)=\rho$. The deposit insurance liability of the government reaches $b^{*}$, determined by the tax rate $\tau^{*}$.

After $\widehat{T}$, banks will only be able to meet the withdrawal demands of depositors by reducing outstanding loans to corporate borrowers. This requires the repayment of loan principal by firms. The entire banking 
system faces net withdrawal demand at $\widehat{T}$ in equilibrium, so that no firm would be able to reduce its debt to one bank by borrowing from another. An existing or new firm could not buy all or part of the firm's capital either, since it would not be able to get a loan from a bank to finance its purchase. In this economy, banks become illiquid at time $\widehat{T}$ because they have no alternative but to face net withdrawals of deposits that cannot be met. A banking crisis must occur, and the government must stop accumulating deposit insurance liabilities.

The capital stock employed by firms can be interpreted as loan collateral in this economy. Prior to the onset of the crisis, one firm can sell its capital to another and repay its loans fully. This makes a market for collateral with an equilibrium price of collateral equal to one. In a crisis, a bank that attempts to reduce its corporate loans to meet deposit withdrawals would discover that its borrowers are unable to repay their loan principals. If banks foreclose loans in the amount of net withdrawal demand by depositors, the collateral on those loans will have a zero price. This is because no firm will be able to borrow to purchase the collateral. The financing is not available because aggregate bank deposits have decreased by exactly the amount of the foreclosed loans. Loans are not available to potential purchasers of the seized collateral in equilibrium with irreversible investment. There will be no demand for collateral at a positive price in the crisis even though the marginal productivity of capital is positive.

This implies a collapse in the market for collateral in a banking crisis. If banks are heterogenous and become liquidity constrained idiosyncratically, then a decline in the value of collateral (that is, a decrease in Tobin's $q$ ) could result. Bank heterogeneity could be introduced to the model economy by adding assumptions that lead banks to incomplete diversify their loan portfolios in equilibrium (for example, allowing a finite number of firms and increasing returns to scale in banking). This would make the deposit insurance liability and current earnings of each bank depend on the particular history of productivity shocks for its corporate clients. Over time, some banks will earn less from lending than others and might eventually be unable to meet the withdrawal demands of depositors from their net earnings on loans. Banks that do well can acquire borrowers as banks that do poorly shrink.

However, in the presence of deposit insurance with regulatory forbearance, banks that do well pay out dividends to shareholders only over a finite horizon just as in our model of homogeneous banks. New loans generate future dividends for shareholders only until the accumulation of deposit insurance liabilities by the government stops. Therefore, we should expect that the value of collateral will fall as more and more banks become insolvent up to the onset of a banking crisis or the end of regulatory forbearance (the interpretation of what happens if $T$ is less that $\widehat{T}$ ). Alternatively, with continuously enforced loan-loss reserves, the price of collateral, $q$, would remain equal to one in this economy. 
For many years, the Government of Japan dealt with the problem of troubled banks through the "convoy system," under which weak banks would be merged with strong banks. Under the convoy system the losses of a weak bank are absorbed by the shareholders of the strong bank. An interpretation is that the shareholders of a strong bank absorb the equivalent of the deposit insurance liability in these forced mergers. In this interpretation of the convoy system, the dividends paid to the shareholders of the weak bank are eventually financed by transfers from the shareholders of the strong bank rather than from taxpayers.

This interpretation also suggests that the convoy system should break down. The managers of the strong banks face the same incentives to accumulate deposit insurance claims as do the shareholders of the weak banks. In a heterogeneous economy, their loan portfolios performed well ex post, so that their net asset incomes are higher those that of weaker banks, but the convoy system taxes the higher returns to pay for (past) dividends paid to the shareholders of the weaker banks. It transfers equity from the owners of stronger banks to weaker banks in expectation. When a bank becomes a convoy leader, its shareholder value falls. Therefore, the maximization of shareholder returns implies that a bank should avoid becoming a convoy leader by paying out all the dividends it can over the same horizon as the rest of the banking sector.

In the fiscal policy adopted in our discussion of the analytical model, the tax rate, $\tau$, was constant after date $T$. This kept the public debt to output ratio constant. Alternative fiscal policies under which the government delays raising revenue or adopts a time-varying tax rate could also be used. For example, regulatory authorities could intervene in the banking system at time $T^{\prime}$ with public sector deposit insurance liability equal to $b_{T^{\prime}}$, and fiscal authorities could wait to raise taxes until time $\widehat{T}$. The tax rate imposed at time $\widehat{T}$ will need to be sufficient to service the accumulated public debt $e^{r\left(\widehat{T}-T^{\prime}\right)} b_{T^{\prime}}$. With irreversible investment, the growth rate goes to zero at time $\widehat{T}$ if the tax rate implied by this debt level reduces the post-tax rate of return to deposits to the household discount rate. Other possible policy responses include imposing taxes so that $b$ stays constant as the economy grows or $b$ is reduced to zero over some finite horizon. In these cases, the tax rate varies over time. If the deposit insurance liability declines in proportion to output, then the tax rate falls over time and the growth rate of output will rise again. Under these types of fiscal responses, our model would imply a temporary, perhaps sharp, fall in the growth rate of gross domestic output, followed by a recovery.

The model makes two policy assumptions: the deposit insurance liability is not continuously borne by the banks through insurance premium payments and is ultimately financed by a proportional tax on deposits. Both of these are essential to the equilibrium dynamics. The first assumption fits Japan 
where very little of the cost of risky portfolio choices are borne by bank shareholders. Correct pricing of risk for risk-taker would be the opposite of regulatory inadequacy and forbearance modeled here. Using lump-sum taxes would eliminate the growth effects in the model with a representative agent. In an overlapping generations model, the endogenously growing deposit insurance liability could still depress growth if it is financed through lump-sum taxes which redistribute across generations. Intergenerational redistribution in an overlapping generations model also implies that current generations can benefit through the accumulation of public sector liabilities at a cost to future generations. This gives a simple model for motivating regulatory forbearance in the first place. ${ }^{10}$

\section{Empirical Tests of Asset Prices and Fundamentals}

Before we apply our model to the Japanese experience, we first test whether asset prices correctly reflect economic fundamentals. This is because our model imposes perfect foresight, ruling out bubbles and implying that all asset prices reflect fundamentals. The stock market values of corporations (25), and of the banking sector (24) are assumed to equal the present discounted value of dividends. The deposit insurance liability of the government depends on the growth of stock market values (13), and since the flow-budget identity for the representative household depends on this deposit insurance liability (government debt), the behavior of consumption and other real variables in our model depends on the assumption that stock prices reflect fundamental values. Thus, it is important to ascertain whether bubbles exist, and whether stock values reflect fundamentals. Here we perform some tests, showing that for Japan's recent history, our assumption that asset prices reflect fundamentals is basically correct.

Campbell, Lo, and MacKinlay ([1997], p. 260) and others argue that bubbles in stock prices are inconsistent with stationary stock returns if the dividend process follows a linear process with a unit root. They also show that prices and dividends, and prices and earnings should be cointegrated. In fact, rational bubbles in stock prices may imply that the series of stock prices, stock returns, dividend-price ratios, and earnings-price ratios follow an explosive process, in which the series keep on increasing to infinity (See Appendix).

\subsection{Unit Root Tests for Bubbles in Stock Prices, Dividends, and Earnings}

The validity of these stationarity relationships can be seen in Figures 1-3, and in Table 1. Although the relations in equations (1)-(3) are expressed in terms of levels, Campbell, Lo, and MacKinlay ([1997], p. 261) show that they are also valid in terms in logs, if dividends follow a loglinear process. From Figures 1-3, we can see that log stock price changes look like a stationary series. This is corroborated in the 
Phillips-Perron unit root tests of Table 1, which shows, for all periods, a rejection of the hypothesis that log stock price changes are nonstationary.

If $\log$ prices and $\log$ dividends are cointegrated, then the log dividend-price ratio should be stationary. From Figure 1, however, the log dividend-price ratio looks like a non-stationary series. Phillips-Perron unit root tests show that for the 1980Q2-2002Q2, and 1991Q1-2002Q2 periods, we can reject the null hypothesis of nonstationarity at the 10 percent level, although for the 1980Q2-1990Q4 period, we cannot reject the null-hypothesis of nonstationarity.

Similarly, from Figure 2, the log price-earnings ratios looks like a non-stationary series. Phillips-Perron unit root tests show that for all periods, we cannot reject the hypothesis that the log price-earnings ratio is nonstationary.

Finally, since short-term interest rates are used to discount future dividends, we examine the behavior of short-term interest rates (the call rate) in Figure 3. Short-term interest rates appear to be stationary until the end of 1991. Clearly, since 1992, short-term interest rates appear non-stationary.

Overall, these results suggest that while the evidence for the existence of bubbles is not compelling, we cannot entirely reject the existence of bubbles, especially in the 1980Q2-1990Q4 period, when there is no cointegration between stock prices and dividends or earnings. However, the balance of evidence suggests that our fundamentals assumption is reasonable.

\subsection{Fundamentals, Bubbles, and the Predictability of Stock Returns}

If stock returns are predictable from fundamentals, then bubbles, even if they exist, are small, and are probably not important in affecting stock returns. Table 2 shows some long-horizon regressions, relating stock returns on various fundamentals at horizons of 1 quarter, 4 quarters ( 1 year), and 12 quarters (3 years). The fundamentals we examine are the log price-earnings ratio, the log dividend-price ratio, and the short-term interest rate. As it is well-known, forecast accuracy increases remarkably as the horizon increases. The coefficients, R-squareds, and T-statistics all increase, as the forecast horizon increases. For example, as the current log price-earnings ratio increases, stocks become overvalued and this overvaluation is corrected after 4 quarters or so. That is, high log price-earnings ratios imply low stock returns, at medium to long horizons. The coefficients on the log-price earnings ratios are negative. A high current $\log$ dividend-price ratio implies increasing stock returns. Finally, high current short-term interest rates predict high stock returns at long-horizons. ${ }^{11}$

Table 3 depicts the relationship between fundamentals and stock returns in a VAR framework. It appears that some fundamentals have explanatory power, over and beyond lagged stock returns. Both the dividend-price and the price-earnings ratios have high explanatory power. The moderately high R-squared 
values suggests a modest degree of forecastability for quarterly stock returns. In the last column of Table 3, we added first-differences of the variables that are included in our Vector Autoregression estimates in Section 7. The first difference of lagged credit (actually, the credit-GDP ratio) is highly significant, although none of the other variables are significant. The R-squared value of 0.29 again suggests a moderate degree of forecastability.

Overall, these results suggest that fundamentals have good forecasting power, especially at longhorizons. Furthermore, fundamentals appear to have forecasting power, over and beyond lagged stock returns. These results suggest that fundamentals are important in explaining Japanese stock returns, and that the role of bubbles in affecting stock returns, may be small or superfluous.

\section{Application of the Model to the Japanese Economy in the 1990s}

In the theoretical model, a banking crisis and growth collapse develops endogenously in the absence of effective prudential regulation in an economy without aggregate production risk and under perfect foresight. Idiosyncratic production risk across firms creates individual loan losses that can be exactly offset by profits on other loans but are not when banks are able to pay out dividends against deposit insurance liabilities subsidized by the government. We argue that the practice of prudential supervision and regulation in Japan over the last two decades matches our assumptions very well. In this section, we consider how well the predictions of the model fit Japanese economic performance.

The model predicts dynamics for investment, consumption, output, bank credit growth, asset prices and the value of collateral assets before and after the crisis that can be compared to the data. Some empirical implications of the model are:

1. As the banking system accumulates a deposit insurance claim in the form of non-performing corporate loans against which dividends were paid, the growth rate of output decreases steadily to its post-crisis level and consumption rises as a share of output under perfect foresight.

2. The stockmarket value of the corporate sector can grow more rapidly than output before the crisis is realized for the empirical plausible case of inelastic intertemporal substitution $(\sigma>1)$.

3. The stockmarket value of the banking sector will decline before the crisis, implying that we should observe a decrease in the value of bank stocks relative to the aggregate value of the stock market before the banking crisis. ${ }^{12}$

4. The value of collateral in the model equals $q_{t} k_{t}$ which grows proportionately with output until output growth falls to zero in a banking crisis and the market for collateral collapses. ${ }^{13}$

Two of the many simplifying assumptions of the model are important to reconsider for comparing its 
equilibrium dynamics to the empirical record for Japan. The first is the assumption of full information under perfect foresight. In equilibrium, the output share of investment decreases gradually to its long-run value and consumption rises steadily to its long-run share before the banking crisis. Households and firms may be imperfectly informed and receive information over time about the health of the banking sector or future fiscal policies under rational expectations. When there is news about bank balance sheets or the government's expected response to deposit insurance losses, investment and GDP growth can change suddenly. The second issue is that aggregate productivity for Japan fluctuates. A temporary adverse aggregate productivity shock would lead to a permanent rise in non-performing loans held by the bank sector, moving the beginning of a crisis forward in the model economy. Therefore, such a shock would have a permanent effect on GDP growth under rational expectations.

It is difficult to identify the beginning of the banking crisis in Japan. At least two dates can be suggested readily. In 1992, the Japanese Ministry of Finance first acknowledged rising non-performing bank loans publicly. This followed the beginning of the sharp deterioration of Japanese economic performance in the early 1990s. The second possibility is 1997 to early 1998, when several financial institutions, including banks (Nippon Credit Bank and Hokkaido Takushoku) and major securities companies (Sanyo and Yamaichi securities) collapsed. At the same time, the East Asian financial crisis of 1997-98 provided a major international shock to the Japanese economy. In the interpretation of the model, either or both of these dates may be times that households and firms receive news about problems in the banking sector. The realization that banks have large and growing non-performing assets in the early 1990s could reveal information that starts investment and output growth on the adjustment path predicted by the model as the banking sector deteriorates further. The accumulation of deposit insurance losses may not have ended yet, so that date $T$ in the model may not have been reached. Therefore, we need to remain agnostic about the timing of the onset of the banking crisis.

\subsection{Output growth, consumption and investment}

The growth rate of GDP declines leading up to the banking crisis in equilibrium for the model. Figure 4 (from Dekle and Kletzer [2003]) shows a significant decline in the GDP growth rate for Japan over the three years, 1990 through 1992. Although we cannot make a judgement about when the future costs of bank bailouts were recognized by investors and savers, but the decline in the growth rate to lower levels that persist (and worsen) to the present is consistent with the model.

The growth rate of consumption does not fall before the 1990s, but begins to decline as the GDP growth rate fell in 1990. Figure 4 also shows a slight rise in consumption as a share of GDP beginning in 1990. This is also consistent with the model because consumption growth does not fall as much as output 
growth does. In response to economic performance, the government of Japan increased transfer payments to households in the 1990s. This could contribute to a smaller contraction in household consumption as a share of GDP and may helped sustain consumption growth. Hayashi and Prescott [2002] argue that regulatory changes in the 1980s reduced the incentives of households to supply labor, leading to a rise in leisure consumption by about 20 percent. If consumption of goods and leisure are complements, then these changes could raise the share of consumption in output.

Figure 4 also shows that investment growth does not decline before 1990 as it would if savers and investors anticipated the growth in non-performing bank loans and public sector liabilities that would be recognized in the early 1990s. The figure shows a decline in the share of investment in GDP after 1990 as predicted by our model. These data are consistent with the interpretation that the news of the impending banking crisis arrives after the end of the 1980s. Indeed, the share of investment in GDP rises in the late 1980s before the onset of the Japanese growth collapse. Our basic model does not imply these dynamics, but a rise in investment share is implied by our agency model (Dekle and Kletzer [2002a and b]. That model suggests that extending our current model by allowing adverse selection in investment projects by firms could lead to an increase in the growth rate of the capital stock before a crisis.

A drop in investment may be reflected in investment in research and development or the adoption of technological innovations and be under estimated by the rate of capital accumulation. Investment in new technologies may generate returns over longer average horizons than aggregate capital formation. In Japan, between 1970-80 and 1990-98, total factor productivity (TFP) growth rates dropped from 1.1 percent per annum to 0.2 percent per annum. The decline in TFP was especially sharp in manufacturing, where TFP growth dropped from 4.9 percent to 0.5 percent per annum. With regards to other measures of productivity, return on equity fell from 12 percent in 1980 to 4 percent in 1998; and the return on invested capital fell from 6 percent in 1980 to 4 percent in 1998. These compare with 1998 returns on equity and invested capital in the United States of 22 percent and 14 percent respectively. ${ }^{14}$

\subsection{Bank credit growth}

Total bank credit in the model equals the sum of firm capital stocks and the deposit insurance claims accumulated by banks, $k+b$. This sum equals the total bank deposits held by households and grow as a share of GDP up to the crisis. Bank credit as a share of GDP should stop rising when a banking crisis occurs and should decline if the deposit insurance liabilities of the government are expected to be cleared in finite time. Figure 5 shows that these dynamics correspond roughly to the data for Japan and that there is a distinct change in the growth rate for the ratio of bank credit to GDP in 1991. This is consistent with our dating of the beginning of the banking crisis in the early 1990s followed by a deepening of the crisis in 
1997-98.

\subsection{Non-performing bank loans and land prices}

An important implication of the model is that the stock market value of domestic banks should be declining up to time $T$. The stock market value of the corporation sector also grows faster than GDP in equilibrium before the crisis and drop to the growth rate of GDP after the crisis in the model. Because the collapse of the Nikkei bubble of the 1980s would also cause a decline in bank stocks, the distinguishing feature of the model is that the ratio of the value of domestic bank equities to the value of the entire stock market should decline once the private sector realizes the deterioration of the banking sector. The ratio of the stock market value of the banks to the total value of the stock market started to decline sharply in 1987, at least 3-4 years before the beginning of the crisis, as shown in Figure 6 (from Dekle and Kletzer [2003]). This is consistent with the prediction, special to our model, that the ratio of bank stock values to total stock values leads other macroeconomic aggregate measures. Because asset prices are very responsive to new information regarding future dividend growth and real interest rates, we argue that this offers good evidence in favor of a model based on rational expectations in which consumption and investment are forward-looking.

In the model economy, the decline in the quality of bank portfolios leading up to a crisis is gradual and caused by prospective government bailouts. The share of non-performing loans (NPLs) to total bank loans rises steadily before the crisis. Reliable NPL data are available only after 1992, when the Ministry of Finance first recognized the NPL problem (again, a sudden change in the information of investors and savers). The ratio of non-performing loans to total bank loans over the 1990s is shown in Figure 7 from Dekle and Kletzer [2003]. Non-performing loans were 2 percent of GDP between 1992 and 1994, rose sharply to about 5 percent of GDP in 1996 and were 7 percent of GDP in 2000.

Land is not included in the theoretical model, but land is important as collateral for a large proportion of bank lending in Japan. Between 1980 and 1995, about 40 percent of all corporate borrowing was collateralized by real estate (Ueda [2000]). The value of the capital stock with irreversible investment in the model, however, parallels the value of other fixed assets that serve as collateral. The total value of collateral suddenly falls in a banking crisis in the model. The dramatic decline in the value of land in Japan during the 1990s parallels the collapse in the value of capital predicted by the model. Average land prices in Japan declined by about 60 percent between 1992 and 2000, as shown on Figure 7. A common hypothesis that the increase in the price of real estate over the 1980s contributed to an expansion in bank credit, which in turn lead to higher rates of investment and economic growth. ${ }^{15}$ The causality predicted by our model runs the opposite direction. 


\subsection{Vector Autoregression Estimates}

Our model yields relationships between the ratio of the value of bank stocks to the total stock market value and subsequent investment, output growth, and bank credit growth. For example, a tightening of prudential supervision and regulatory enforcement will reduce and $\mathrm{T}$. This immediately lowers the bank equity ratio, and subsequently raises the path of investment (as a ratio of GDP), lowers the growth rate of bank credit to GDP and the present value of collateral assets (as a ratio of GDP).

We test our theoretical prediction that the future paths of investment, bank credit, and the value of collateral respond to shocks to the ratio, but not the converse. We first estimate Vector Autoregressions (VAR) with the relevant variables, and then perform Granger causality tests to examine whether the bank equity ratio is exogenous in the Granger sense. If so, the bank equity ratio temporally precedes the other variables in our Vector Autoregression. The VAR is formed using four variables, the bank stock to the total stock market value ratio, the investment to GDP ratio, the bank credit to GDP ratio, and an index of land prices. Although land prices are not modeled directly, our model does capture the value of capital as collateral which becomes a fixed asset in a crisis. This mimics land prices in a crisis, so we apply the implications of the model for the value of collateral to land prices.

Table 4 depicts the VAR results with our four variables: BSTS (the bank equity ratio), CRED (the ratio of bank credit to GDP), INVEST (the investment to GDP ratio), and LANDPRIC (land prices). The optimal lag length of two was chosen by the Akaike Information Criterion. In the BSTS equation, besides its own lagged values, none of the other variables are significant. In the CRED equation, besides its own lagged values, only LANDPRIC lagged once is significant. In the INVEST equation, besides its own lagged values, both LANDPRIC lagged once and twice are significant. In the LANDPRIC equation, none of the other variables are significant.

We next perform Granger causality tests to ascertain whether one variable temporally precedes another. In a VAR framework, Granger causality tests are Chi-squared tests of exclusion of all the lags of a particular variable. For example, BSTS Granger causes CRED if BSTS(-1) and BSTS(-2) are jointly significant in the CRED equation, but CRED(-1) and $\operatorname{CRED}(-2)$ are not jointly significant in the BSTS equation.

Table 5 depicts the results of the Granger causality tests in a VAR framework. In the BSTS equation, none of the variables are significant. In fact, besides lagged BSTS, none of the variables contribute any explanatory power. In the CRED equation, BSTS and LANDPRIC provide good explanatory power. In the INVEST equation, BSTS and LANDPRIC again provide good explanatory power. In the LANDPRIC equation, none of the variables are significant.

Taken together, these results are consistent with our theory. BSTS temporally precedes (Granger causes) 
CRED and INVEST. That is, shocks to BSTS such as a tightening of prudential regulations raises INVEST and CRED. BSTS does not temporally precede LANDPRIC. That is, BSTS and LANDPRIC appear to be simultaneously determined. This is consistent with models in which as asset prices, both equity and land prices respond to correlated future fundamentals.

\section{Conclusion}

Japan has historically had a bank-centered financial system, or relationship banking, where the long-term and tight relationship between banks and corporate borrowers dominated financial intermediation. The efficient functioning of relationship banking requires an effective mechanism to discipline banks to ensure the prudent monitoring of debtor firms. As Horiuchi [2003] notes, it is difficult for outside investors to effectively monitor bank management under relationship banking. For example, it is very difficult for outsider investors to assess the quality of bank loans, creating the need for an agent to monitor and discipline bank managers. Traditionally, the bank regulatory authority (in Japan's case, the Banking Bureau of the Ministry of Finance and the Financial Supervisory Agency) serves as monitor of bank portfolios and the actions of bank managers.

We have shown in this paper that the current difficulties faced by government regulators for resolving the Japanese banking crisis follow from a recent history of regulatory forbearance and the failure to fulfill this monitoring role. In this paper, we present a model in which regulatory forbearance, accompanied by a high corporate reliance on bank borrowing and government implicit and explicit deposit insurance, can lower the long-run growth rate of the economy and result in an endogenous banking crisis. The model shows that deposit guarantees and slack financial regulation create incentives for banks to make transfers to bank shareholders or depositors that are financed by the public sector, hence taxpayers in the future. The accumulated, unrealized, deposit insurance liability of the government to the banking sector is the public debt used to finance such transfers. Banks accumulate this public debt on the asset side of their balance sheets in the form of non-performing loans, acknowledged or unacknowledged. In common usage, a banking crisis is not clearly defined. In our model economy, the banking sector will deteriorate to the point of a liquidity crisis with certainty unless regulatory forbearance ends and effective prudential regulations are enforced that impose continuous loan-loss reserving, or its equivalent. One may wish to label the event of a rising and irreversible deposit insurance liability for the government that must result in a sharp policy reversible to avoid a crisis for investment finance a banking crisis. This is exactly what happens in our model if the government steps in before the liquidity crisis occurs or not.

In our analysis, deposit insurance liabilities affect economic growth because public debt increases lower 
aggregate wealth in the presence of distortionary taxes. Allowing these debts to accumulate lowers the growth rate further, so that postponing regulatory intervention leads to larger declines in GDP growth. This also holds true if the government continues to accumulate net deposit insurance liabilities after a banking crisis begins. The model has two major policy implications. The first is that enforcement of individual loan-loss reserves or loan write-downs eliminates the ability of bank managers to finance transfers to shareholders or depositors from the public sector. The model also supports prompt intervention (for example, implementation of Prompt Corrective Action in the case of Japan). Because the growth rate of the model economy falls as deposit insurance liabilities rise against dividends paid out to shareholders or depositors, the economy cannot grow out of the problem in an equilibrium. 


\section{Appendix}

Applying Campbell, Lo, and MacKinlay [1997], with constant interest rates, the stock price can be written as:

$$
P_{t}=E_{t} \sum_{i=1}^{\infty}\left(\frac{1}{1+r}\right)^{i} D_{t+i}+E_{t} \frac{B_{t+1}}{(1+r)},
$$

where $P_{t}$ is the stock price at time $t, D_{t+i}$ is the dividend at time $t+i, r$ is the interest (discount) rate, and $B_{t+1}$ is the bubbles component. The bubbles component is the deviation of the price from the fundamental value of stocks or the present discounted value of dividends.

Equation (A1) can be re-written as

$$
P_{t}=D_{t} \sum_{i=1}^{\infty}\left(\frac{1}{1+r}\right)^{i}+E_{t} \frac{B_{t+1}}{(1+r)}
$$

if the $E_{t} D_{t+i}=D_{t}$, for each $i$. When there is no bubble component and $D_{t+i}$ follows a random walk, $P_{t}$ also follows a random walk. Therefore, the change in prices, $\Delta P_{t}$, is a stationary process.

Furthermore, by subtracting a multiple of the dividend from both sides of (A1), we obtain

$$
P_{t}-\frac{D_{t}}{r}=\frac{1}{r} E_{t} \sum_{i=1}^{\infty}\left(\frac{1}{1+r}\right)^{i} \Delta D_{t+1+i}+E_{t} \frac{B_{t+1}}{(1+r)}
$$

A random walk in dividends implies that the change in dividends is a stationary process. Thus, from (A3), we can again see that if there is no bubbles component, the stationarity of the change in dividends implies that $P_{t}-\frac{D_{t}}{r}$ is a stationary process. That is, $P_{t}$ and $D_{t}$ are cointegrated. Further, if dividends are a constant fraction of earnings, $D_{t}=\gamma Q_{t}$, then (A3) implies that stock prices and earnings are also cointegrated.

All of these relationships - the stationarity of the change in prices, the existence of cointegration between

stock prices and dividends, and stock prices and earnings - break down when bubbles exist, and $E_{t} \frac{B_{t+1}}{(1+r)}$ is nonzero. Moreover, the existence of rational bubbles imply that

$$
\lim _{i \rightarrow \infty} E_{t} \frac{B_{t+i}}{(1+r)^{i}}
$$

That is, the bubble on stock prices is expected to be non-zero into the infinite future. The intuition is simply that today, people will not pay in excess of the fundamental value of the stock, unless they can expect to unload the stock for higher than fundamental value tomorrow. Likewise, tomorrow, people will not pay above fundamental value, unless they can expect to unload the stock for higher than fundamentals the day after tomorrow, and so on. In fact, with stationary dividends, at each date, people will expect the bubble to 
increase at a rate greater than the interest rate, to compensate for the probability of bursting. Clearly, (A4), as it enters into (A1) and (A3) will violate the condition that $\Delta P_{t}, P_{t}-\frac{D_{t}}{r}$ and $P_{t}-\frac{\gamma Q_{t}}{r}$ are stationary processes. 


\section{Endnotes}

${ }^{1}$ This interpretation is explained at length in Cargill, Hutchison, and Ito [1997], Hutchison [1998], Hoshi and Patrick [2000], Hoshi and Kashyap [1999], Hoshi and Kashyap [2002].

${ }^{2}$ Cargill, Hutchison, and Ito [1997] draw a comprehensive picture of the causes of the banking crisis in Japan. They emphasize the role played by monetary policy in precipitating the banking crisis. They suggest that the sudden shift to a tighter monetary policy in 1989 led to asset deflation and the resulting collapse of land prices led to a rise in non-performing loans. Our non-monetary model shows how bank lending with inadequate regulation can also lead to a bank crisis.

${ }^{3}$ The derivation of simple loan contracts is explained in Freixas and Rochet [1997].

${ }^{4}$ Showing this is straightforward for the assumed uniform distribution of firm productivity. It is laborious and beside the point of our paper.

${ }^{5}$ The agency model used in Dekle and Kletzer [2002a and b] is similar to that proposed by Chinn and Kletzer [2001] for the East Asian crisis.

${ }^{6}$ Depositor monitoring of each bank's accounts would allow reputational equilibria, for example.

${ }^{7}$ This is a consequence of perfect foresight. Suppose taxes were non-distortionary (lump sum) so that Ricardian equivalence held. The household would save all its dividend income in deposits to pay future taxes, so that increased savings would match the rise in the deposit insurance liabilities. With distortionary taxes, the deposit insurance claims of the banking sector net of the future taxes they imply are a negative addition to wealth, adding to the rise in saving.

${ }^{8}$ For example, Hayashi and Prescott [2002] assume that $1 / \sigma=0.5$ in their calibrated model for Japan.

${ }^{9}$ In our model, the positive value of bank equity derives from this policy combination because it allows banks to pay out dividends against uncollected corporate interest.

${ }^{10}$ Takeo Hoshi suggested this route for using redistribution from future taxpayers to current depositors and shareholders. Allowing within generation heterogeneity in a political economy model would also.

${ }^{11}$ However, Campbell, Lo, and MacKinlay ([1997], p. 265) caution that when expected returns are simply persistent, we can obtain the results in Table A2 of long-horizon forecastability spuriously. 
${ }^{12}$ Under perfect foresight, corporate stock values grow in proportion to gross domestic product after the crisis for a constant tax rate. If the tax rate varies over time (for example, to eliminate the deposit insurance liability, $b$, in finite time), the growth rate of the value of the stock market will be different than the growth rate of output during the transition to the long-run simply because the value of equity is a forward-looking variable. Therefore, it should not be taken as a prediction of our model that the value of the stock market grows with output after time $T$ because its behavior will depend on the policies adopted to resolve the crisis or private sector expectations with respect to these policies.

${ }^{13}$ Investment irreversibility is used in the model for analytical simplicity. If smooth adjustment costs to disinvestment were introduced, then a banking crisis would result in corporate bankruptcies and a falling price of capital, $q_{t}$. While the model shows that transactions in collateral should drop to zero in a crisis, it also implies that under more general adjustment costs the value of collateral should fall below the growth rate of output in a crisis.

${ }^{14}$ The data reported in this paragraph are from Fukao, Inui, Kawai, and Miyagawa [2002].

${ }^{15}$ This is argued, for example, by Ogawa and Kitasaka [2000] and by Ueda [2000]. 


\section{References}

Barseghyan, Levon [2002], "Non Performing Loans, Prospective Bailouts, and Japan's Slowdown,” manuscript, Northwestern University.

Bayoumi, T. [2001], "The Morning After: Explaining the Slowdown in Japanese Growth in the 1990s," Journal of International Economics, 53, April, pp. 241-59.

Campbell, John, Andrew Lo and A. Craig MacKinlay [1997], The Econometrics of Financial Markets, Princeton: Princeton University Press.

Cargill, Thomas [2000], "What Caused Japan's Banking Crisis?," in Takeo Hoshi and Hugh Patrick, eds., Crisis and Change in the Japanese Financial System, Norwell, MA: Kluwer Academic Publishers.

Cargill, Thomas, Hutchison, Michael, and Takatoshi Ito [1997], The Political Economy of Japanese Monetary Policy, Cambridge, MA: MIT Press.

Chinn, Menzie and Kenneth Kletzer [2000], "International Capital Inflows, Domestic Financial Intermediation and Financial Crises under Imperfect Information,” in Reuven Glick, Ramon Moreno and Mark Spiegel, eds., Emerging Market Crises, New York: Cambridge University Press, pp. 196-237.

Dekle, Robert and Kenneth Kletzer [2002a], "Domestic Bank Regulation and Financial Crises: Theory and Empirical Evidence from East Asia," in Jeffrey Frankel and Sebastian Edwards, eds., Preventing Currency Crises in Emerging Markets, Chicago: The University of Chicago Press.

Dekle, Robert and Kenneth Kletzer [2002b], "Financial Intermediation, Agency and Collateral and the Dynamics of Banking Crises: Theory and Evidence for the Japanese Banking Crisis," Federal Reserve Bank of San Francisco, Conference on "Financial Issues in the Pacific Basin Region," September 26-27.

Dekle, Robert and Kenneth Kletzer [2003], "The Japanese Banking Crisis and Economic Growth: Theoretical and Empirical Implications of Deposit Guarantees and Weak Financial Regulation,” Journal of the Japanese and International Economies, 17, pp. 305-335.

Diamond, Douglas [1984], "Financial Intermediation and Delegated Monitoring," Review of Economic Studies, 51, pp. 393-414.

Diamond, Douglas and Phillip Dybvig [1983], “Bank Runs, Deposit Insurance and Liquidity,” Journal of Political Economy, 91, June, pp. 401-419.

Freixas, Xavier and Jean-Charles Rochet [1997], Microeconomics of Banking, Cambridge, MA: MIT Press.

Fukao, Kyoji, Inui, Tomohiko, Kawai, Hiroki, and Tsutomu Miyagawa [2002], "Sectoral Productivity and Economic Growth in Japan: 1970-98," manuscript, Hitostubashi University.

Grimes, William [2001], Unmaking the Japanese Miracle, Ithaca: Cornell University Press.

Hamilton, James [1994], Time Series Analysis, New Jersey: Princeton University Press.

Hayashi, Fumio and Edward Prescott [2002], “The 1990s in Japan: A Lost Decade,” manuscript, University of Minnesota. 
Hoshi, Takeo and Anil Kashyap [1999], "The Japanese Banking Crisis: Where Did It Come from and How Will it End," in Ben Bernanke and Jerome Rotemberg, eds., NBER Macroeconomics Annual, 1999, Cambridge: MIT Press.

Hoshi, Takeo and Anil Kayshap [2001], Corporate Financing and Governance in Japan, Cambridge: MIT Press.

Hoshi, Takeo and Hugh Patrick [2000], "The Japanese Financial System: An Introductory Overview," in Takeo Hoshi and Hugh Patrick, eds., Crisis and Change in the Japanese Financial System, Norwell, MA: Kluwer Academic Publishers.

Horiuchi, Akiyoshi [2003], “A Bank Crisis in a Bank Centered Financial System-The Japanese Experience Since the 1990s," mimeographed, Chuo University.

Hutchison, Michael [1998], “Are all Banking Crisis Alike?” University of California, Santa Cruz, Working Paper.

Ito, Takatoshi [2000], “The Stagnant Japanese Economy in the 1990s: The Need for Financial Supervision to Restore Sustained Growth," in Takeo Hoshi and Hugh Patrick, eds., Crisis and Change in the Japanese Financial System, Norwell, MA: Kluwer Academic Publishers.

Kwon, E. [1998], "Monetary Policy, Land Prices, and the Collateral Effects on Economic Fluctuations: Evidence from Japan,” Journal of Japanese and International Economies, 12, pp. 175-203.

Ogawa, Kazuo and Shinichi Kitasaka [2000], "Bank Lending in Japan: Its Determinants and Macroeconomic Implications," in Takeo Hoshi and Hugh Patrick, eds., Crisis and Change in the Japanese Financial System, Norwell, MA: Kluwer Academic Publishers.

Townsend, Robert M. [1979], "Optimal Contracts and Competitive Markets with Costly State Verification,” Journal of Economic Theory 21, no.2 (October), pp. 265-93.

Ueda, Kazuo [2000], “Causes of Japan's Banking Problems in the 1990s,” in Takeo Hoshi and Hugh Patrick, eds., Crisis and Change in the Japanese Financial System, Norwell, MA: Kluwer Academic Publishers. 
Table 4.1. Phillips-Perron Unit Root Statistics

\begin{tabular}{l|lll}
\hline Dates & $1980 Q 2-2002 Q 2$ & $1980 Q 2-1990 Q 4$ & 1991Q1-2002Q2 \\
\hline Stock Returns & $-6.1^{* * *}$ & $-3.2^{*}$ & $-5.3^{* * *}$ \\
Dividend-Price Ratio & -1.5 & -0.98 & -1.5 \\
\hline Price-Earnings Ratio & $-2.3^{*}$ & -1.7 & $-2.3^{*}$ \\
\hline
\end{tabular}

Rejection of Null Hypothesis of Unit Root:

*** Significant at 1 percent level.

** Significant at 5 percent level.

* Significant at 10 percent level. 
Table 4.2. Long-Horizon Regressions of Stock Returns on Log Price-Earnings and Log Dividend-Price Ratios, and Short Term Interest Rates

\begin{tabular}{l|ccc}
\hline & \multicolumn{3}{|c}{$\begin{array}{c}\text { Forecast Horizon } \\
\text { (Quarters) }\end{array}$} \\
\hline & \multicolumn{2}{|c}{$\mathbf{4}$} & $\mathbf{4}$ \\
Log Price-Earnings & & & \\
Coefficient & -0.0076 & -0.15 & -0.58 \\
R-squared & 0.0017 & 0.099 & 0.39 \\
T-statistic & -0.41 & -2.29 & -5.18 \\
Log Dividend Price & & & \\
Coefficient & -0.017 & 0.18 & 0.73 \\
R-squared & 0.067 & 1.95 & 0.45 \\
T-statistic & -0.77 & 0.09 & 5.53 \\
Short Term Interest & & & \\
Coefficient & 0.0027 & 0.017 & 0.059 \\
R-squared & 0.011 & 0.056 & 0.17 \\
\hline T-statistic & -0.096 & 1.36 & 3.05 \\
\hline
\end{tabular}

Standard-Errors are Newey-West.

Sample: 1980:2-2002:2. 
Table 4.3. Fundamentals and Stock Returns

Dependent Variable: Stock Returns

(Sample: 1980Q2-1997Q4)

\begin{tabular}{|c|c|c|c|}
\hline Constant & 0.022 & 0.036 & -0.0007 \\
\hline & $(0.95)$ & $(1.96)$ & $(-0.69)$ \\
\hline Stock Returns (-1) & 0.13 & 0.22 & $\ldots$ \\
\hline & $(0.81)$ & $(1.51)$ & \\
\hline Stock Returns (-2) & -0.11 & -0.84 & $\ldots$ \\
\hline & $(-0.92)$ & $(-0.69)$ & \\
\hline Dividend-Price (-1) & $\begin{array}{l}-0.29 \\
(-2.21)\end{array}$ & $\ldots$ & $\cdots$ \\
\hline Dividend-Price (-2) & $\begin{array}{c}0.33 \\
(2.55)\end{array}$ & $\ldots$ & $\ldots$ \\
\hline Price-Earnings (-1) & $\ldots$ & $\begin{array}{l}0.17 \\
(2.09)\end{array}$ & $\ldots$ \\
\hline Price-Earnings (-2) & $\ldots$ & $\begin{array}{l}-0.25 \\
(-3.04)\end{array}$ & $\ldots$ \\
\hline Short-Term Interest (-1) & $\begin{array}{l}0.0053 \\
(0.39)\end{array}$ & $\begin{array}{l}0.0063 \\
(0.49)\end{array}$ & $\ldots$ \\
\hline Short-Term Interest (-2) & $\begin{array}{l}-0.0053 \\
(-0.39)\end{array}$ & $\begin{array}{l}-0.16 \\
(-1.14)\end{array}$ & $\cdots$ \\
\hline Ch.(INVEST (-1)) 1/ & $\ldots$ & $\ldots$ & $\begin{array}{l}0.0057 \\
(0.21)\end{array}$ \\
\hline Ch.(INVEST (-2)) & $\ldots$ & $\ldots$ & $\begin{array}{l}0.0062 \\
(0.22)\end{array}$ \\
\hline Ch. (CRED(-1)) 2/ & $\ldots$ & $\ldots$ & $\begin{array}{l}8.89 \\
(1.35)\end{array}$ \\
\hline Ch. $(\operatorname{CRED}(-2))$ & .. & $\ldots$ & $\begin{array}{l}18.84 \\
(2.85)\end{array}$ \\
\hline Ch. (LANDPRIC (-1)) 3/ & $\ldots$ & $\ldots$ & $\begin{array}{l}0.00017 \\
(0.41)\end{array}$ \\
\hline Ch. (LANDPRIC(-2)) & $\ldots$ & $\ldots$ & $\begin{array}{l}-0.00035 \\
(-0.89)\end{array}$ \\
\hline R-squared: & 0.27 & 0.29 & 0.29 \\
\hline Adj. R-squared: & 0.19 & 0.22 & 0.19 \\
\hline
\end{tabular}

T-statistics in parentheses.

1/ First Difference of the Lagged Investment-Output Ratio.

2/ First Difference of the Lagged Credit-Output Ratio.

3/ First Difference of the Lagged Landprice. 
Table 4.4. VAR Estimates of the Model

\begin{tabular}{l|llll}
\hline \multicolumn{1}{c|}{ Equation } & BSTS & CRED & INVEST & LANDPRIC \\
\hline Variable & & & & \\
BSTS (-1) 1/ & 1.09 & 0.00043 & 0.023 & 36.71 \\
& & & & \\
& $(9.75)$ & $(0.15)$ & $(0.0039)$ & $(1.01)$ \\
BSTS(-2) & -0.16 & 0.0022 & 0.79 & -12.29 \\
& $(0.11)$ & $(0.75)$ & $(1.28)$ & $(-0.33)$ \\
CRED(-1) 2/ & 1.16 & 0.76 & -8.83 & 250.9 \\
& $(0.25)$ & $(6.62)$ & $(-0.36)$ & $(0.17)$ \\
CRED(-2) & -3.42 & 0.14 & 2.44 & 522.7 \\
& $(-0.80)$ & $(1.36)$ & $(0.11)$ & $(0.38)$ \\
INVEST(-1) 3/ & -0.011 & -0.00048 & 0.068 & 4.63 \\
& $(-0.52)$ & $(-0.91)$ & $(0.59)$ & $(0.68)$ \\
INVEST(-2) & -0.0021 & 0.00026 & 0.0031 & -0.15 \\
& $(-0.099)$ & $(0.48)$ & $(4.61)$ & $(7.02)$ \\
LANDPRIC(-1) $4 /$ & 0.000021 & 0.0000064 & -0.0029 & 1.91 \\
& $(0.17)$ & $(2.08)$ & $(-4.51)$ & $(47.6)$ \\
LANDPRIC(-2) & 0.000055 & -0.0000055 & -0.0029 & -0.95 \\
& $(0.45)$ & $(-1.71)$ & $(-4.49)$ & $(23.78)$ \\
CONSTANT & 0.61 & 0.014 & 1.58 & -202.96 \\
& & & & $(-1.91)$ \\
R-squared: & $(0.33)$ & $(1.71)$ & $(0.89)$ & 0.99 \\
& 0.94 & 0.98 & 0.98 & 0.79 \\
\hline Adj. R-squared: & & & & \\
\hline
\end{tabular}

1/ Bank Stock Equity-Total Stock Market Equity Ratio.

2/ Ratio of Credit to GDP.

3/ Investment to GDP Ratio.

4/ Land Prices. 
Table 4.5. Granger Causality/Chi-squared Exogeneity Test

\begin{tabular}{|l|l|l|l|l|l|l|l|l|}
\hline & \multicolumn{2}{|c|}{ BSTS 1/ } & \multicolumn{2}{c|}{ CRED 2/ } & \multicolumn{2}{c|}{ INVEST 3/ } & \multicolumn{2}{c|}{ LANDPRIC 4/ } \\
\hline $\begin{array}{l}\text { Excluded } \\
\text { Variable }\end{array}$ & Chi-sq & Prob5/ & Chi-sq & Prob. & Chi-sq & Prob. & Chi-sq & Prob. \\
\hline BSTS & 3.41 & 0.18 & 5.94 & 0.05 & 12.81 & 0.0016 & 3.65 & 0.16 \\
\hline CRED & 3.11 & 0.21 & 6.11 & 0.03 & 0.81 & 0.62 & 3.21 & 0.18 \\
\hline INVEST & 2.93 & 0.23 & 1.91 & 0.38 & 0.73 & 0.69 & 3.09 & 0.21 \\
\hline LANDPRIC & 4.13 & 0.13 & 5.17 & 0.07 & 21.3 & 0 & 3.35 & 0.19 \\
\hline
\end{tabular}

1/ Bank Stock Equity-Total Stock Market Equity.

2/ Ratio of Credit to GDP.

3/ Investment to GDP Ratio.

4/ Land Prices.

5/ Probability Value. 
Figure 4.1. Stock Returns and the Dividend-Price Ratio

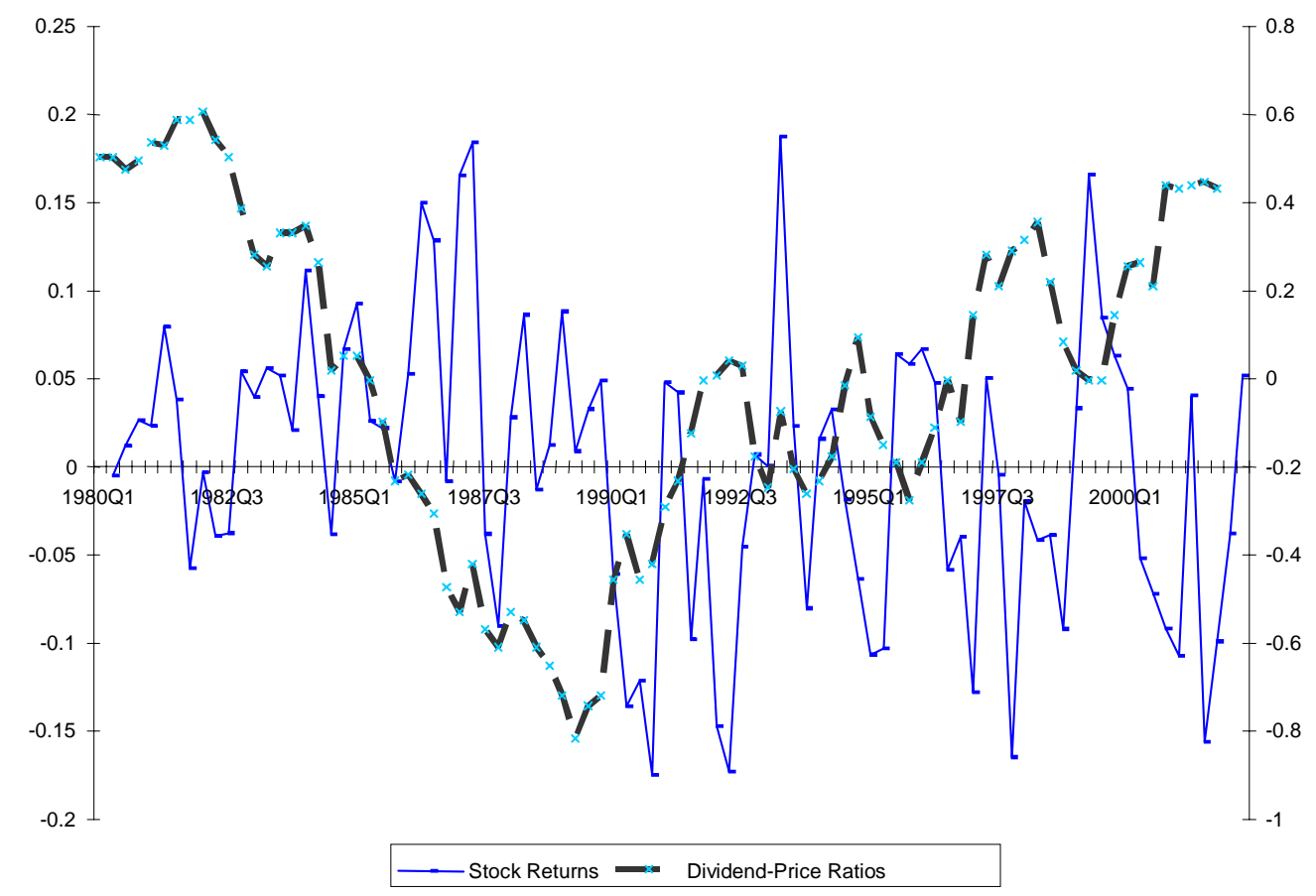


Figure 4.2. Stock Returns and the Price-Earnings Ratio

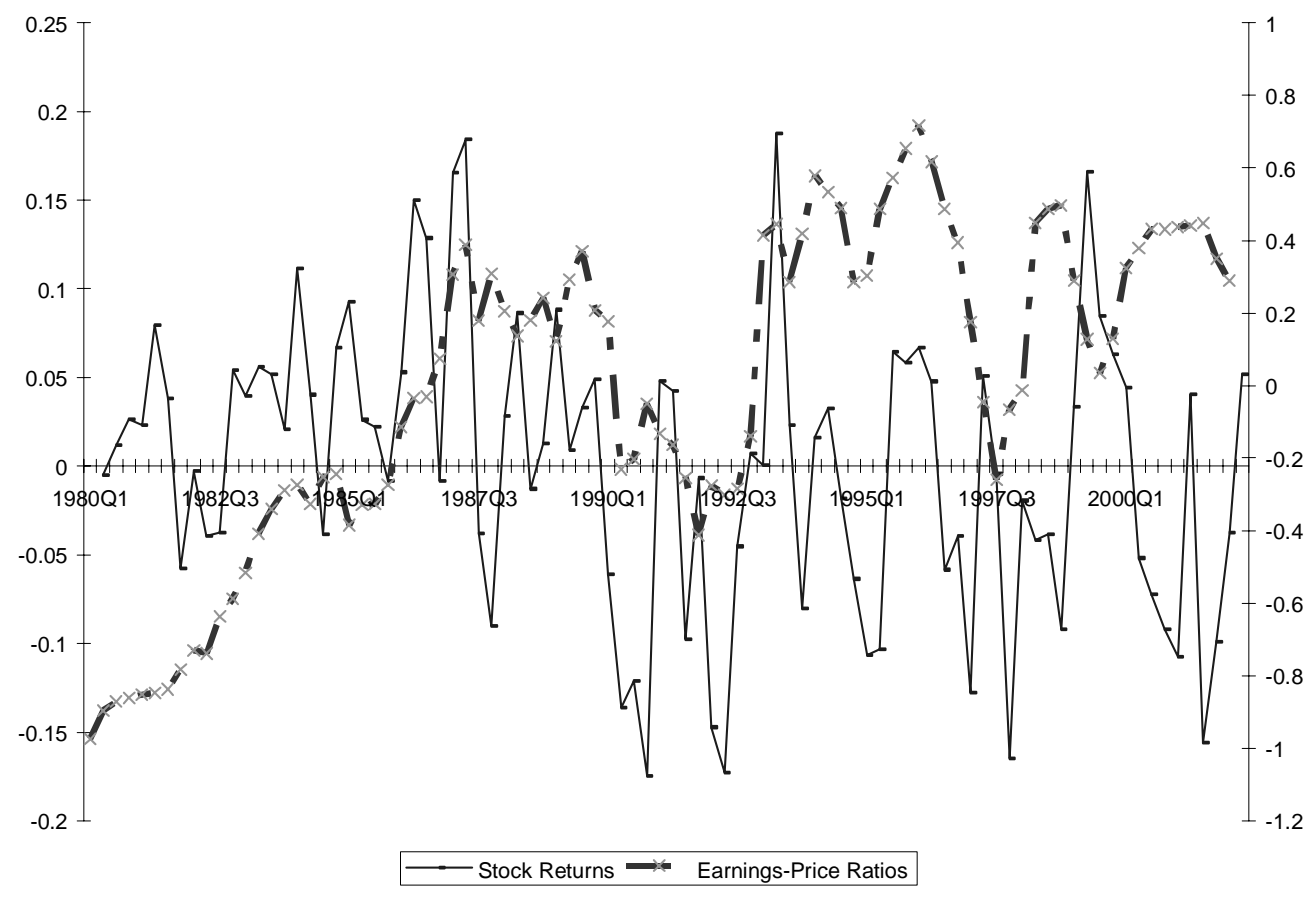


Figure 4.3. Stock Returns and Short-term Interest Rates

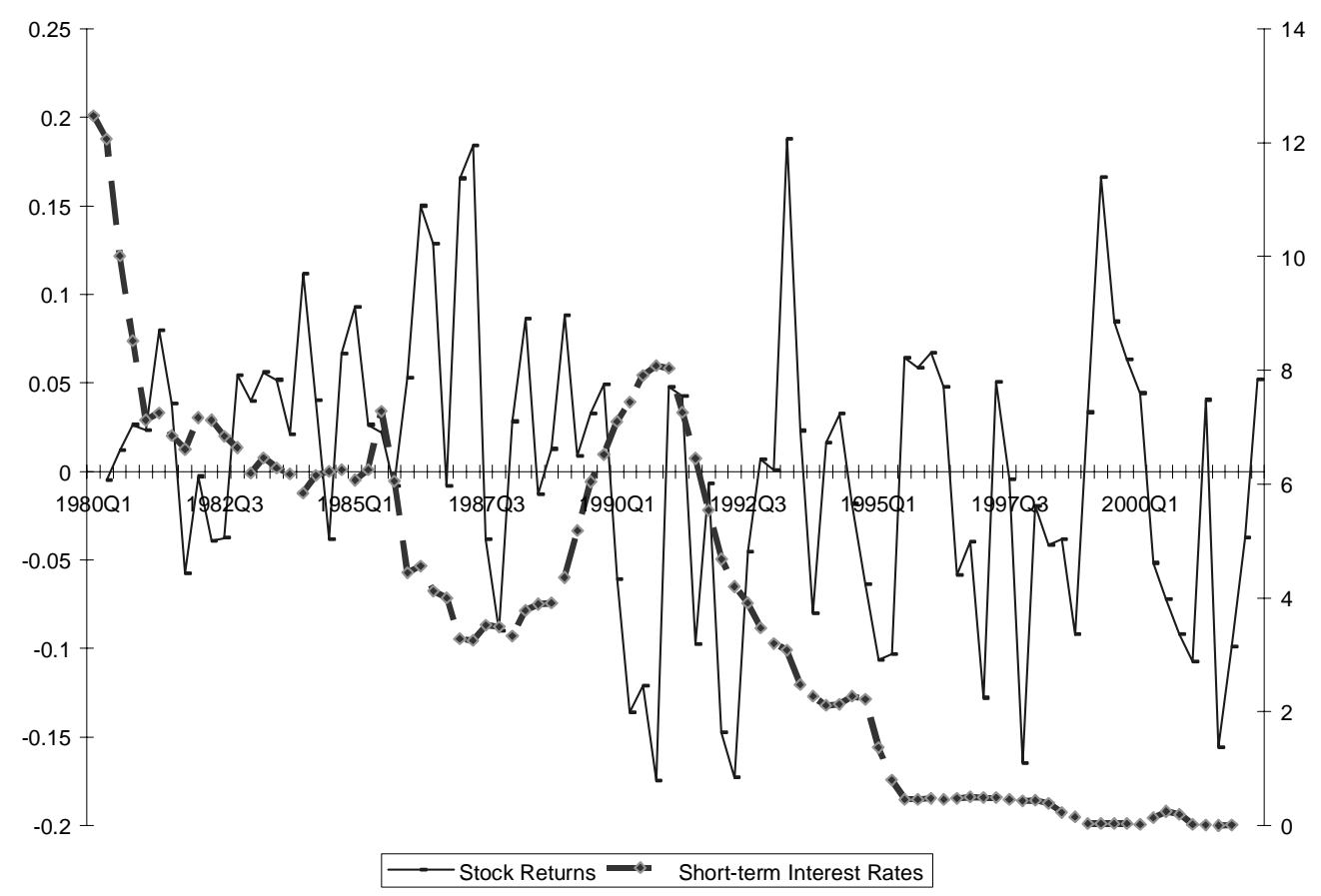


Figure 4.4. Consumption and Investment-GDP Ratios, GDP Growth Rate

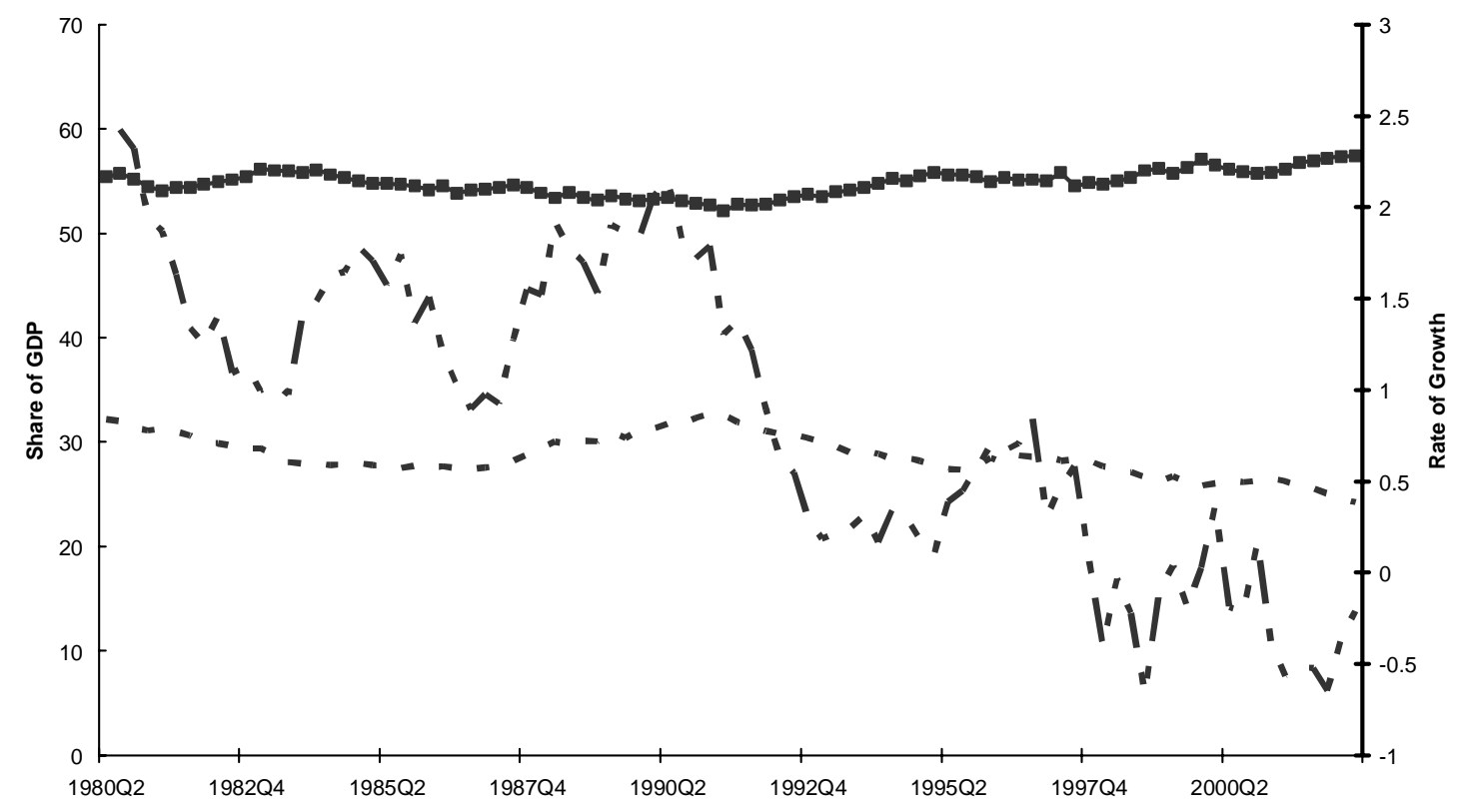

$\rightarrow$ Consumption Rate - - Investment Rate - - Real GDP Growth 
Figure 4.5. Credit Growth

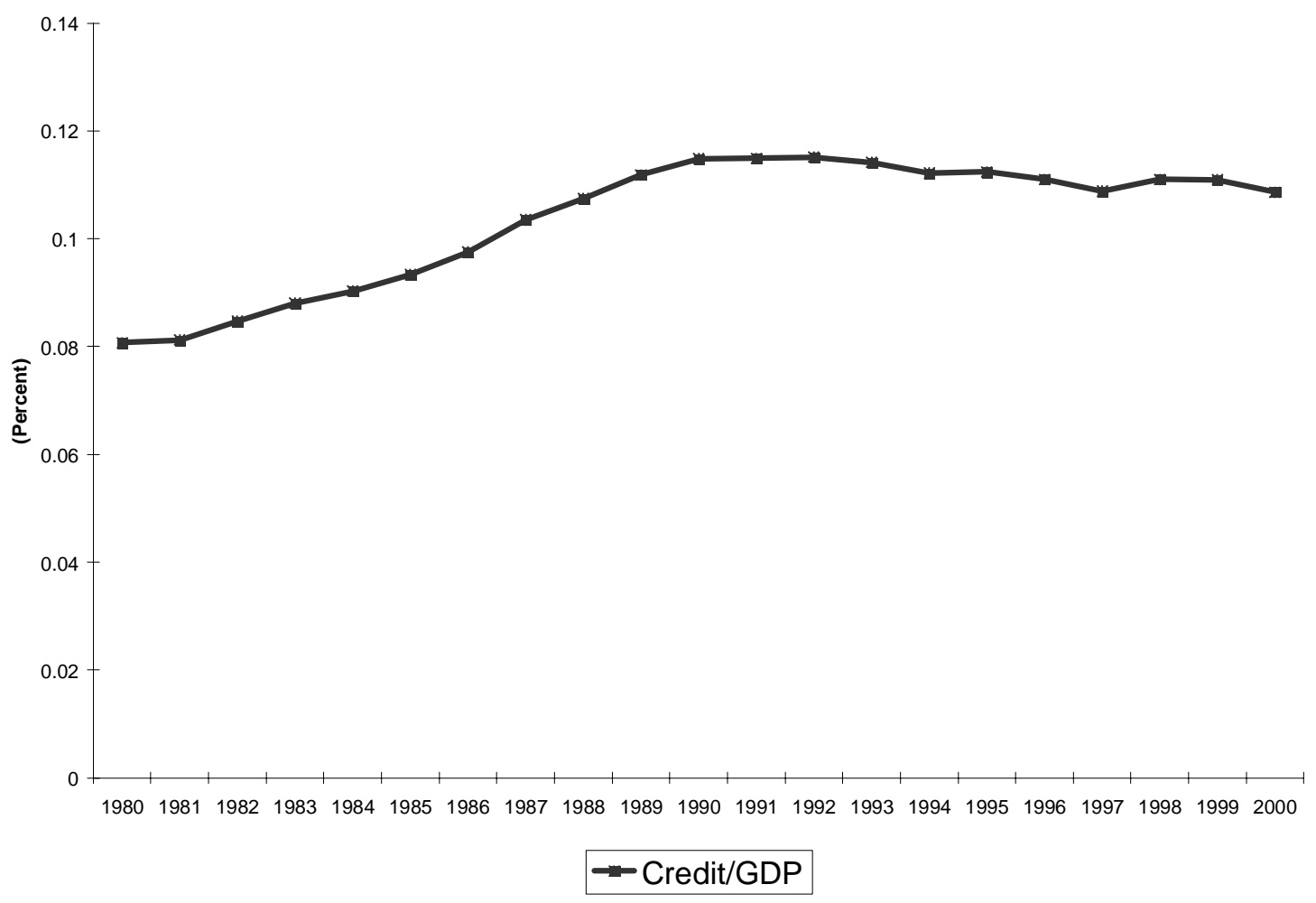


Figure 4.6. Ratio of Bank Stock Value/Total Stock Market Value

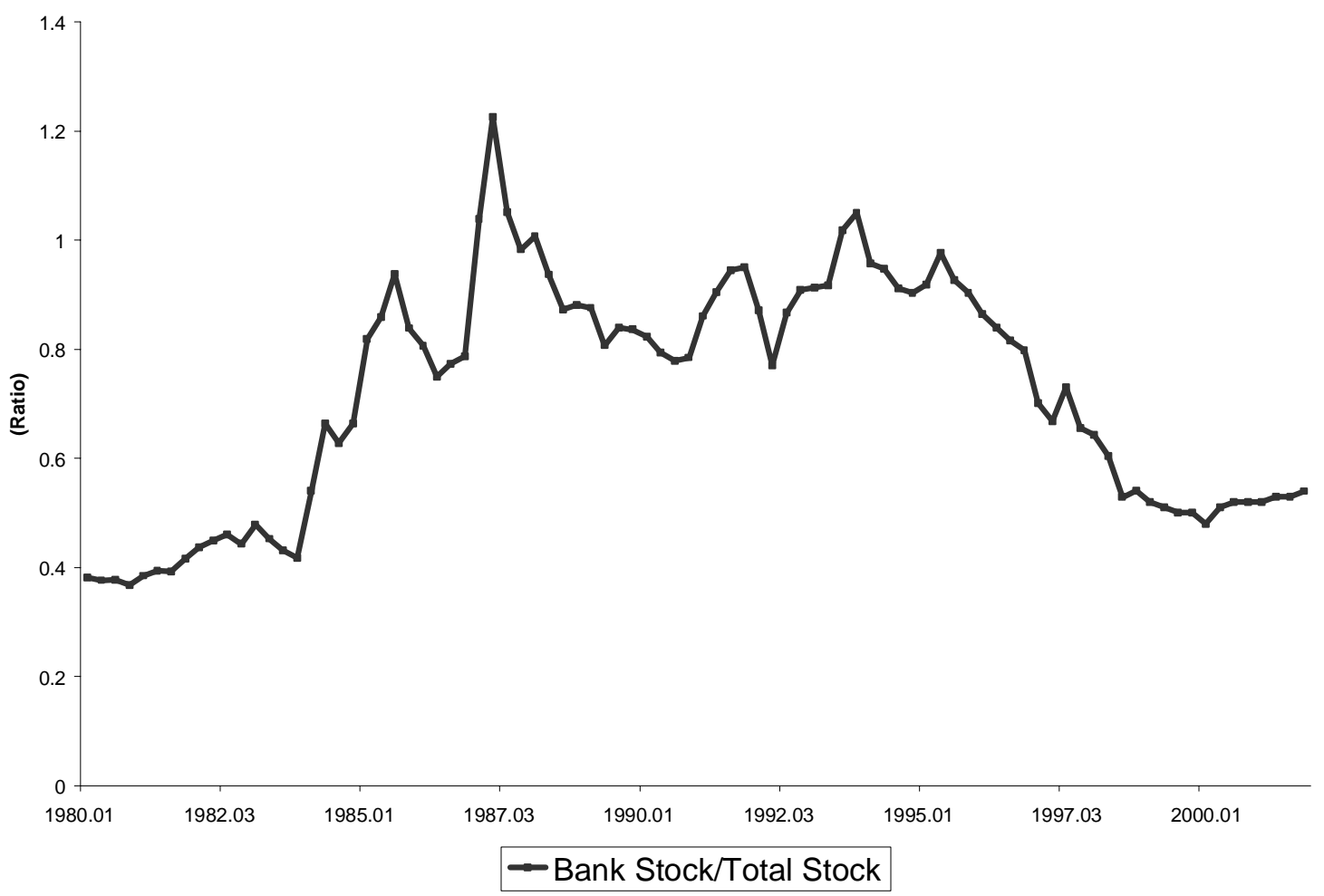


Figure 4.7. Non-performing Loans and Land Prices

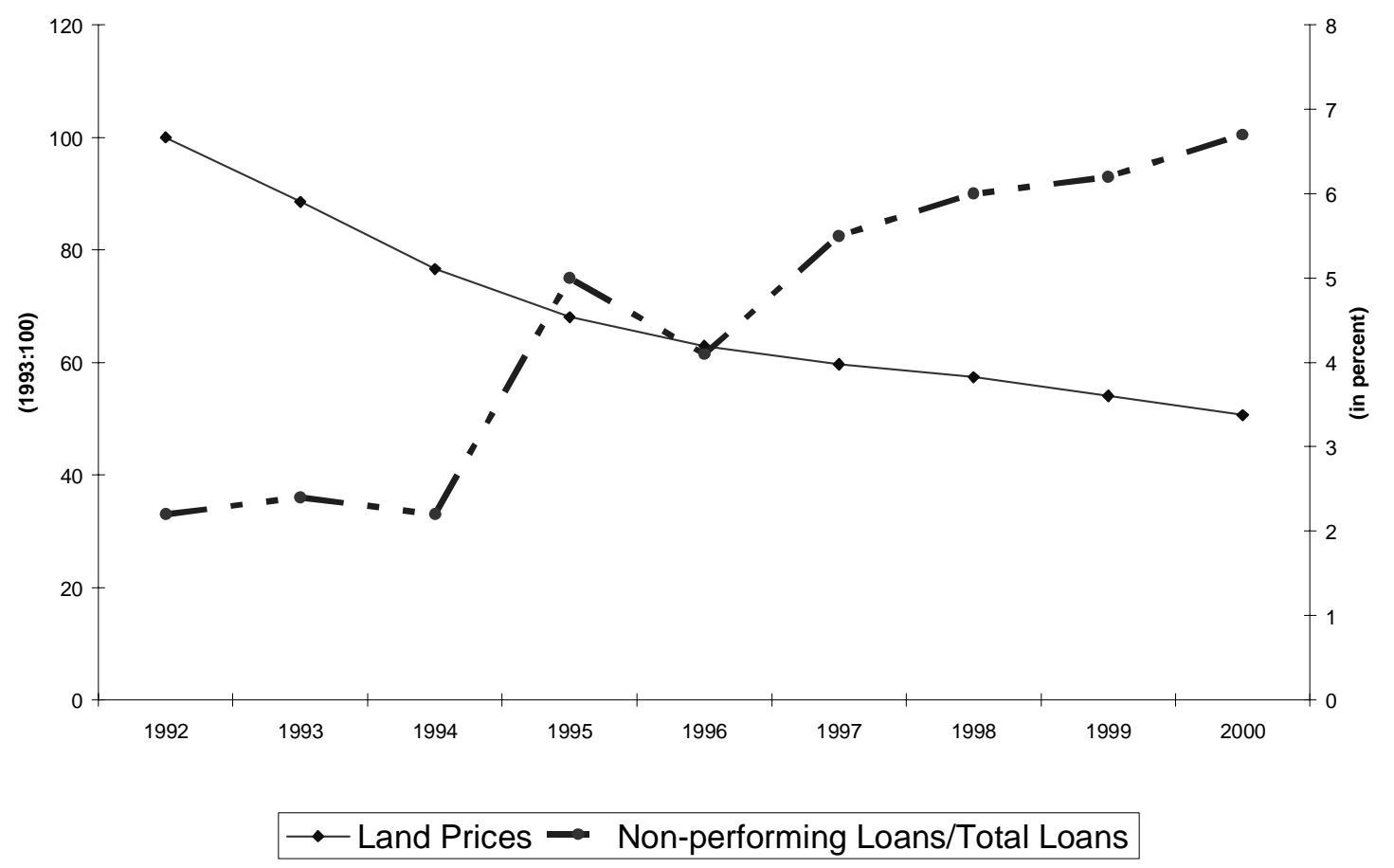

